\title{
WHAT'S (STILL) WRONG WITH CREDIT RATINGS?
}

\author{
Frank Partnoy*
}

\begin{abstract}
Scholars and regulators generally agree that credit rating agency failures were at the center of the recent financial crisis. Congress responded to these failures with reforms in the 2010 Dodd-Frank Act. This Article demonstrates that those reforms have failed. Instead, regulators have thwarted Congress's intent at every turn. As a result, the major credit rating agencies continue to be hugely profitable, yet generate little or no informational value. The fundamental problems that led to the financial crisis-overreliance on credit ratings, a lack of oversight and accountability, and primitive methodologies---remain as significant as they were before the financial crisis. This Article addresses each of these problems and proposes several solutions.
\end{abstract}

First, although Congress attempted to remove credit rating agency "regulatory licenses," the references to ratings in various statutes and rules, regulatory reliance on ratings remains pervasive. This Article shows that regulated institutions continue to rely mechanistically on ratings and demonstrates that regulations continue to reference ratings, notwithstanding the Congressional mandate to remove references. This Article suggests several paths to reduce reliance.

Second, although Congress authorized new oversight measures, including an Office of Credit Ratings (OCR), that oversight has been ineffective. Annual investigations have uncovered numerous failures, many in the same mortgage-related areas that precipitated the financial crisis, but regulators have imposed minimal discipline on violators. Moreover, because regulators refuse to identify particular rating agencies in OCR reports, wrongdoers do not suffer reputational costs. This Article proposes reforms to the OCR that would enhance its independence and sharpen the impact of its investigations.

Third, although Congress authorized new accountability measures, particularly removing rating agencies' exemptions from liability under section 11 of the Securities Act of 1933 and Regulation FD, the Securities and Exchange Commission has gutted both of those provisions. The SEC performed an end-run around Dodd-Frank's explicit requirements, reversing the express will of Congress. Litigation has not been effective as an accountability measure, either, in part because rating agencies continue to assert the dubious argument that ratings are protected speech. This Article argues that the SEC should reverse course and implement Congress's intent, including encouraging private litigation.

* George E. Barrett Professor of Law and Finance, University of San Diego. I am grateful for useful comments from Laura Adams, Anat Admati, Ken Ayotte, Jordan Barry, Robert Bartlett, Jonathan Berk, John Cochrane, Lynne Dallas, Alexander Dill, Michael Dorff, Aaron Edlin, Jill Fisch, Victor Fleischer, Dov Fox, Mark Gergen, Jonathan Glater, Michael Guttentag, Robert Jackson, Summer Kim, Prasad Krishnamurthy, Omri Marian, Therese Maynard, Shaun Martin, Justin McCrary, Robert Merges, David Min, James Park, Paul Pfleiderer, Elizabeth Pollman, Joshua Rauh, Myron Scholes, Amit Seru, Tom Smith, Mila Sohoni, Steven Davidoff Solomon, Ahmed Taha, Randall Thomas, Shannon Trevino, and Benjamin Van Rooij, and to Temasek for financial support. 
Finally, given the ongoing problems in these three areas, it is no surprise that credit rating agency methodologies remain unreliable. This Article concludes by illustrating the weakness of current methodologies with a particular focus on the treatment of diversification and investment holding companies. This Article argues that neither regulators nor investors should rely on such crude and uninformative methodologies.

This Article's overarching recommendation is straightforward: both regulators and investors should reduce reliance on credit ratings, and regulators should implement Congress's will with respect to rating agency oversight and accountability. Credit rating agencies are a cautionary example of regulatory stickiness, meaning that reliance on ratings has proven difficult to undo. More generally, the stickiness of regulatory licenses is a warning for policymakers who are considering deferring to private entities for regulatory purposes in other areas.

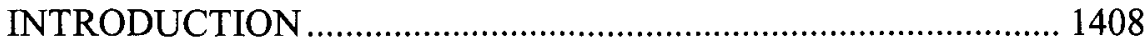

I. THE LEGACY OF REGULATORY LICENSES ....................... 1419

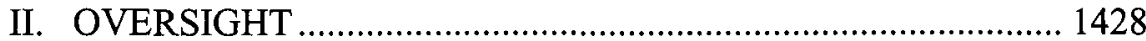

A. The Office of Credit Ratings .......................................... 1428

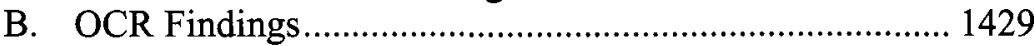

C. Limitations on the OCR .................................................. 1432

III. ACCOUNTABILITY …………………………................... 1433

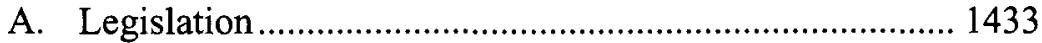

1. Section 11 ............................................................. 1434

2. Regulation FD...................................................... 1436

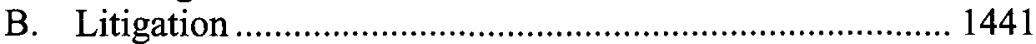

IV. METHODOLOGIES …………………………..................... 1445

A. An Overview of Corporate Rating Methodology ............. 1446

1. Business Risk.......................................................... 1446

2. Financial Risk Assessment ......................................... 1451

3. Anchor Rating........................................................... 1453

4. Discretion and Subjective Adjustments to Credit

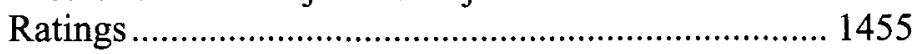

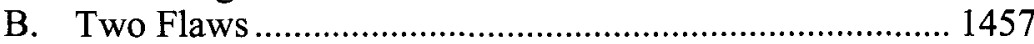

1. Diversification ............................................................ 1457

2. Investment Holding Companies ................................. 1462

\section{INTRODUCTION}

Academics have long recognized the unique and important role of credit rating agencies in financial markets. ${ }^{1}$ During the 1980 s and 1990 s,

1. Credit rating agencies have been a topic of academic interest since well before the recent financial crisis. See GILBERT HAROLD, BOND RATINGS AS AN INVESTMENT GuIDE: AN APPRAISAL OF THEIR EFFECTIVENESS 6-9 (1938) (discussing the history of credit ratings and the increased reliance on ratings in the aftermath of the 1929 market crash); W. BRADDOCK HICKMAN, CORPORATE BOND QUALITY AND INVESTOR EXPERIENCE (1958) (analyzing default rates based on different ratings categories); Frank Partnoy, The Siskel and Ebert of Financial Markets?: Two 
the scholarly consensus about credit rating agencies centered on the "reputational capital" view-a theory, based on information economics, ${ }^{2}$ that credit rating agencies survived and prospered based on their ability to generate and aggregate credible information about debt issues. ${ }^{3}$ The essence of the reputational capital view is that credit rating agencies fill an important need arising from the information asymmetry between issuers and investors: credit rating agencies are reputational intermediaries that bridge the information gap, not unlike restaurant or movie reviewers, except that they use letters (such as AAA) instead of stars or tomatoes. ${ }^{4}$

Beginning in 1999, I set forth a more critical alternative view of credit rating agencies, which I called the "regulatory license" view, based in large part on the empirical observation that regulators and market

Thumbs Down for the Credit Rating Agencies, 77 WASH. U. L.Q. 619, 628-36 (1999) (discussing the early academic literature on credit rating agencies).

2. Information economics dominated the thinking of legal scholars throughout the $1980 \mathrm{~s}$ and 1990s. See generally John C. Coffee, Jr., Market Failure and the Economic Case for a Mandatory Disclosure System, 70 VA. L. REV. 717, 751 (1984); Frank H. Easterbrook \& Daniel R. Fischel, Mandatory Disclosure and the Protection of Investors, 70 VA. L. REV. 669 (1984); Jeffrey N. Gordon \& Lewis A. Kornhauser, Efficient Markets, Costly Information, and Securities Research, 60 N.Y.U. L. REV. 761 (1985); Marcel Kahan, Securities Law and the Social Costs of "Inaccurate" Stock Prices, 41 DuKE L.J. 977 (1992); Paul G. Mahoney, Mandatory Disclosure as a Solution to Agency Problems, 62 U. CHI. L. REV. 1047 (1995); Thomas A. Smith, Institutions and Entrepreneurs in American Corporate Finance, 85 CALIF. L. REV. 1 (1997).

3. For example, Ronald Gilson and Reinier Kraakman described credit rating agencies as one of several reputational intermediaries (including underwriters and auditors) that pledged reputational capital as a commitment to support their role collecting and disseminating information in financial markets. See Ronald J. Gilson \& Reinier H. Kraakman, The Mechanisms of Market Efficiency, 70 VA. L. REV. 549, 604-05 (1984) (describing "information intermediaries" and noting that "in the financial markets, the most obvious example is the role played by rating agencies such as Standard \& Poor's and Moody's"). Similarly, Stephen Choi and Jonathan Macey described credit rating agencies as reputational intermediaries that played a private certification role without regulatory support. See Stephen Choi, Market Lessons for Gatekeepers, 92 Nw. U. L. REV. 916, 934 (1998) (citing Standard \& Poor's and Moody's as examples of how "intermediaries play a certification role without any regulatory intervention"); Jonathan R. Macey, Wall Street Versus Main Street: How Ignorance, Hyperbole, and Fear Lead to Regulation, 65 U. CHI. L. REV. 1487, 1500 (1998) (praising credit rating agencies and concluding: "[i]ndeed, the only reason that rating agencies are able to charge fees at all is because the public has enough confidence in the integrity of these ratings to find them of value in evaluating the riskiness of investments"); George G. Triantis \& Ronald J. Daniels, The Role of Debt in Interactive Corporate Governance, 83 CALIF. L. REV. 1073, 1110 (1995) ("Information intermediaries, such as securities analysts or credit rating agencies, facilitate such conventions by decoding ambiguous signals.").

4. Financial economists have viewed credit ratings as screening mechanisms for information that is unavailable publicly and as attempts to distinguish among issuers of inferior quality and thereby avoid "average quality pricing." See generally George A. Akerlof, The Market for "Lemons": Quality Uncertainty and the Market Mechanism, 84 Q. J. ECON. 488, 488 (1970); Joseph E. Stiglitz, The Theory of "Screening," Education, and the Distribution of Income, 65 AM. ECON. REV. 283, 283 (1975). 
participants increasingly relied on credit ratings in substantive legal rules, and that this regulatory reliance distorted the market for credit ratings. ${ }^{5}$ The essence of the regulatory license view is that credit rating agencies are important, not because they provide valuable information, but because regulatory reliance on credit ratings effectively makes ratings valuable as a kind of financial license that unlocks access to the markets-even if the ratings themselves have little or no informational content.

Before the introduction of regulation, the credit rating business was small and relatively unprofitable. ${ }^{6}$ But, regulatory reliance on credit rating agencies started increasing during the mid-1970s from references in statutes and rules to "Nationally Recognized Statistical Ratings Organizations," or NRSROs, particularly to the two most prominent rating agencies, Moody's Investors Service, Inc. and S\&P Global Ratings Inc., and-to a lesser extent-Fitch Inc.; as regulatory licenses proliferated, NRSROs became both more profitable and less informative. ${ }^{7}$

During the 2000 s, the scholarly literature took multiple perspectives about the above two theoretical frameworks. ${ }^{8}$ On one hand was the argument that, notwithstanding some prominent miscues (such as Enron's investment grade credit ratings shortly before its bankruptcy in 2001), credit ratings overall were correlated with fixed income default experience and arguably reflected at least some information about issuers' creditworthiness. ${ }^{9}$ On the other hand was the argument that regulatory reliance on credit rating agencies continued to increase throughout this time, even while sophisticated market participants viewed credit ratings more skeptically. ${ }^{10}$

5. See Partnoy, Siskel and Ebert, supra note 1, at 683-706 (describing the "regulatory license" view). Other scholars subsequently have noted that the "reputational capital" and "regulatory license" views are the two standard theories about the role of credit rating agencies. See Robert $\mathbf{J}$. Rhee, Why Credit Rating Agencies Exist, 44 ECON. NOTES 161, 168 (2015); Nationally Recognized Statistical Rating Organizations, Exchange Act Release No. 34-72936, 109 SEC Docket 3429 (Oct. 14,2014 ) (to be codified as 17 C.F.R. pts. 232, 240, 249 and $249(\mathrm{~b})$ ) (describing the increase in regulatory reliance on ratings).

6. See Partnoy, Siskel and Ebert, supra note 1, at 636-48.

7. See id. at 692-94.

8. See Jeffrey Manns, Rating Risk After the Subprime Mortgage Crisis: A User Fee Approach for Rating Agency Accountability, 87 N.C. L. REV. 1011 (2009) (giving an overview of credit rating agencies and the problems with their ratings of subprime-backed assets before the crisis).

9. See Claire A. Hill, Regulating the Rating Agencies, 82 WASH. U. L. Q. 43, 44 (2004) (disputing the regulatory license view and the need for reform, and defending the rating agencies as doing a good job providing information).

10. See John C. Coffee, Jr., Gatekeepers: The Professions and Corporate Governance 
Likewise, before 2007, regulators' views of credit rating agencies were mixed. Regulators were sympathetic to the important role of credit ratings in financial markets, but also were critical of potential problems related to that role, including perceptions of agency costs and conflicts of interest. ${ }^{11}$ In 2006, Congress adopted modest reforms to address perceived problems associated with credit rating agencies, even as regulators in a wide variety of areas continued to rely substantively on credit ratings. ${ }^{12}$

Throughout this time, I offered the regulatory license view as a theory to explain the ongoing paradox in fixed income markets: that credit ratings were enormously important, yet possessed little informational value. ${ }^{13}$ I warned regulators and policy makers about the potentially toxic role of credit rating agencies in the use of credit default swaps and the creation of synthetic collateralized debt obligations, or CDOs. ${ }^{14}$ In particular, I criticized the reliance on crude mathematical models that

34, 283-98 (2006) (criticizing credit rating agencies and discussing the regulatory reliance on ratings). Leading institutional investors employed far more sophisticated methodologies than the ones used by the leading credit rating agencies. See Jane Tripp Howe, Credit Analysis for Corporate Bonds, in BOND CREDIT ANALYSIS: FRAMEWORK \& CASE STUDIES (Frank J. Fabozzi ed., 2001); Kamakura Credit Risk, KAMAKURA CORP., http:/www.kamakuraco.com/Solutions/Kamakura RiskManager/CreditRisk.aspx [https://perma.cc/EY9F-FJYR].

11. See Jeffrey Manns, Downgrading Rating Agency Reform, 81 GEO. WASH. L. REV. 749, 750 51 (2013) (describing the bases for various credit rating agency reform approaches).

12. The Credit Rating Agency Reform Act of 2006 provided authority to the SEC to implement registration, recordkeeping, financial reporting, and oversight rules. See Credit Rating Agency Reform Act of 2006, Pub. L. No. 109-291, 120 Stat. 137; SEC, Oversight of Credit Rating Agencies Registered as Nationally Recognized Statistical Rating Organizations, Exchange Act Release No. 34-55857, 17 C.F.R. pts. 240 and 249b (June 5, 2007); SEC, Amendments to Rules for Nationally Recognized Statistical Rating Organizations, Exchange Act Release No. 34-59342, 17 C.F.R. pts. 240 and 240b (Feb. 2, 2009); SEC, Amendments to Rules for Nationally Recognized Statistical Rating Organizations, Exchange Act Release No. 34-61050, 17 C.F.R. pts 240 and 243 (Nov. 23, 2009).

13. See Frank Partnoy, How and Why Credit Rating Agencies Are Not Like Other Gatekeepers, in Financlal Gatekeepers: Can They Protect InVEStors? 59, 61 (Yasuyuki Fuchita \& Robert E. Litan eds., 2006).

14. See id. at 73-80; FRANK PARTNOY, INFECTIOUS GREED: How RISK AND DECEIT CORRUPTED THE FINANCIAL MARKETS 374-92 (2003) (warning about abuses in credit default swaps and CDOs and concluding that CDOs "posed even greater dangers to the global economy"); Letter from Frank Partnoy, Professor of Law, University of San Diego, to Jonathan G. Katz, Sec'y of Sec. \& Exch. Comm'n on Proposed Rule, Definition of Nationally Recognized Statistical Rating Organization, Release No. 34-51572, IC-26834, File No. S7-04-05 (June 9, 2005) (on file with the author); Frank Partnoy, Testimony at Hearings before the United States House of Representatives Subcommittee on Capital Markets, Insurance, and Government Sponsored Enterprises, "Legislative Solutions for the Rating Agency Duopoly" (June 29, 2005). 
did not adequately account for the correlation of CDO assets. ${ }^{15}$ This was all during the early- and mid-2000s, before $2007 .{ }^{16}$

Then came the global financial crisis of 2007-08. The crisis occurred when it became apparent that major financial institutions had used complex and opaque transactions to take on substantial undisclosed exposure to subprime mortgage markets. ${ }^{17}$ The credit rating agencies facilitated these transactions by giving a range of risky financial instruments related to subprime mortgages very high credit ratings; when the subprime mortgage market collapsed, so did these transactions, and crisis ensued.

Numerous scholars chronicled the revelation of bad news about the highly rated fixed income securities at the center of the financial crisis. ${ }^{18}$ After the bankruptcy declaration of Lehman Brothers on September 15, 2008 , the previously mixed assessment of the role of credit rating agencies with respect to such securities became far more critical. ${ }^{19}$

15. See Partnoy, How and Why, supra note 13, at 78 (concluding that the "credit rating agencies are providing the markets with an opportunity to arbitrage the credit rating agencies' mistakes" and that "[ $\mathrm{t}]$ he problems with how CDO pricing models incorporate various measures of correlation among assets are even more troubling").

16. David Skeel and I elaborated on the problems associated with credit derivatives and credit rating agencies in 2007. See Frank Partnoy \& David A. Skeel, Jr., The Promise and Perils of Credit Derivatives, 75 U. CIN. L. REV. 1019 (2007).

17. For a detailed description of the role of the credit rating agencies in the financial crisis, see Frank Partnoy, Overdependence on Credit Ratings Was a Primary Cause of the Crisis, in THE PANIC OF 2008: CAUSES, CONSEQUENCES, AND IMPLICATIONS FOR REFORM (Lawrence Mitchell \& Arthur Wilmarth eds., 2010).

18. See, e.g., Anat admati \& Martin Hellwig, The Bankers' New Clothes: What's Wrong With Banking and What to Do about It (2013); KatHLEen C. ENGel \& Patricia A.

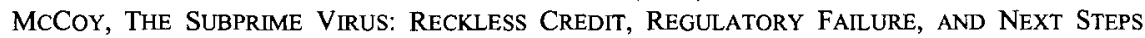
(2011); ERTK GERding, LAW, BubBles, aNd Financial REgUlation (2013); DaVid A. SKeEl, The New Financial Deal: Understanding the DodD-Frank Act and ITS (UNINTENDEd) CONSEQUENCES (2011); DAVID A. WESTBROOK, OUT OF CRISIS: RETHINKING OUR FINANCIAL MARKETS (2009); Anna Gelpern, Financial Crisis Containment, 41 ConN. L. REV. 1051 (2009); Adam Levitin, The Crisis Without a Face: Emerging Narratives of the Financial Crisis, $63 \mathrm{U}$. MiAmi L. REV. 999, 999-1010 (2009); Arthur E. Wilmarth, Jr., The Dark Side of Universal Banking: Financial Conglomerates and the Origins of the Subprime Financial Crisis, 41 CoNN. L. REV. 963 (2009).

19. In the aftermath of the financial crisis, numerous scholars wrote critically about the role of credit rating agencies and potential reform, reaching a wide range of conclusions. See, e.g., Lynn Bai, On Regulating Conflict of Interests in the Credit Rating Industry, 13 N.Y.U. J. LEGIS. \& PUB. POL'Y 253 (2010); John C. Coffee, Jr., Ratings Reform: The Good, The Bad, and The Ugly, 1 HARV. Bus. L. REV. 231 (2011); John P. Hunt, One Cheer for Credit Rating Agencies: How the Mark-to-Market Accounting Debate Highlights the Case for Rating-Dependent Regulation, 60 S.C. L. REV. 749 (2009); Timothy E. Lynch, Deeply Persistently Conflicted: Credit Rating Agencies in the Current Regulatory Environment, 59 CASE W. RES. L. REV. 227 (2009); Manns, supra note 8; Arthur R. Pinto, Control and Responsibility of Credit Rating Agencies in the United States, 54 AM. J. CoMP. L. 341 (2006); Andrew F. Tuch, Multiple Gatekeepers, 96 VA. L. REV. 1583 (2010). 
Government investigations ultimately found that the credit rating agencies, particularly Moody's and S\&P, were central villains in the crisis and that the crisis could not have happened without their misconduct. The Financial Crisis Inquiry Commission called the ratings agencies "key enablers of the financial meltdown." ${ }^{20}$ The U.S. Senate Permanent Subcommittee on Investigations concluded: "[i]naccurate AAA credit ratings introduced risk into the U.S. financial system and constituted a key cause of the financial crisis." 21 The Securities and Exchange Commission and the President's Working Group on Financial Markets reached similar conclusions. ${ }^{22}$

In 2010, Congress passed the Dodd-Frank Act, ${ }^{23}$ which requires federal agencies to replace regulatory references to credit ratings with "appropriate" substitutes. ${ }^{24}$ Dodd-Frank amended the securities laws to enhance the accountability and transparency of credit rating agencies and to create a new Office of Credit Ratings within the SEC to oversee them. ${ }^{25}$ In addition, federal and state prosecutors settled cases against S\&P and Moody's, ${ }^{26}$ and there were a handful of private investor lawsuits. $^{27}$

20. FIN. CRISIS INQUIRY COMM'N, FINANCIAL CRISIS INQUIRY REPORT xxv (2011) ("We conclude the failures of credit rating agencies were essential cogs in the wheel of financial destruction. The three credit rating agencies were key enablers of the financial meltdown. The mortgage-related securities at the heart of the crisis could not have been marketed and sold without their seal of approval. Investors relied on them, often blindly. In some cases, they were obligated to use them, or regulatory capital standards were hinged on them. This crisis could not have happened without the rating agencies. Their ratings helped the market soar and their downgrades through 2007 and 2008 wreaked havoc across markets and firms.").

21. Senate Permanent Subcomm. on Investigations, Wall Street and the Financial CRISIS: ANATOMY OF A FINANCIAL COLLAPSE 6 (2011).

22. See SEC, SUMMARY REPORT OF ISSUES IDENTIFIED IN THE COMMISSION STAFF'S Examinations of Select Credit Rating Agencies 12 n.8 (2008); The President's Working

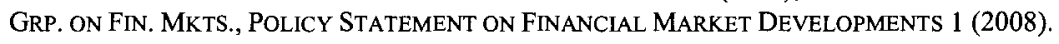

23. Dodd-Frank Wall Street Reform and Consumer Protection Act, Pub. L. No. 111-203, §929Z, 124 Stat. 1376, 1871 (2010) (codified at 15 U.S.C. $§ 780$ ) [hereinafter Dodd-Frank Act]. For a discussion of the Dodd-Frank reforms related to credit rating agencies, see Aline Darbellay \& Frank Partnoy, Credit Rating Agencies Under the Dodd-Frank Act, 30 BANKING \& FIN. SERVS. POL'Y REPORT 1, 2 (2011); Aline Darbellay \& Frank Partnoy, Credit Rating Agencies and Regulatory Reform, in RESEARCH HANDBOOK ON THE ECONOMICS OF CORPORATION LAW (Claire A. Hill \& James L. Krusemark eds., 2012).

24. Dodd-Frank Act $\S 939 A(a)(1)-(2)$, (b).

25. See id. $\S 932$.

26. See Press Release, Dep't of Justice, Justice Department and State Partners Secure $\$ 1.375$ Billion Settlement with S\&P for Defrauding Investors in the Lead Up to the Financial Crisis (Feb. 3, 2015); Moody's Corp., Current Report (Form 8-K) (Jan. 13, 2017).

27. See Moody's Corp., Annual Report (Form 10-K) 105-6 (Feb. 25, 2016) (describing private lawsuits); Carrie Guo, Note, Credit Rating Agency Reform: A Review of Dodd-Frank Section 
This Article assesses these regulatory changes. The overarching point is that they have had little or no impact, and that therefore the same credit rating-related dangers, market distortions, and inefficient allocations of capital that led to the 2007-08 global financial crisis potentially remain today.

Nearly a decade after that crisis, the major credit rating agencies remain among the powerful and profitable institutions in the world. ${ }^{28}$ The market for credit ratings continues to be a large and impenetrable oligopoly dominated by two firms: Moody's and S\&P. ${ }^{29}$ And yet credit ratings are still as uninformative as they were before the financial crisis. ${ }^{30}$ Simply put, credit ratings remain enormously important but have little or no informational value. ${ }^{31}$

933(B)'s Effect (Or Lack Thereof) Since Enactment, 2016 ColuM. Bus. L. REV. 184, 187 n.6 (reviewing federal dockets on PACER and finding only a handful of complaints filed against credit rating agencies since 2010 ).

28. The aggregate market capitalization of the two major credit rating agencies, Moody's Investors Service, Inc. and S\&P Global Ratings Inc., was nearly $\$ 50$ billion in aggregate as of February 2017. See Moody's Corporation (MCO), YAHOO! FINANCE, http://finance.yahoo.com/ quote/MCO?p=MCO [https://perma.cc/85M3-H29C] (Moody's market capitalization of $\$ 19.3$ billion); S\&P Global, Inc., YAHOO! FINANCE, http://finance.yahoo.com/quote/SPGI/?p=SPGI [https://perma.cc/ZFU6-FEAD] (S\&P market capitalization of $\$ 30.1$ billion). Moreover, profitability measures at both Moody's and S\&P are among the highest of any public companies. For example, Moody's 2015 operating margins were forty-two percent higher than the operating margins in any sector of the U.S. economy measured by financial economists, including the peer group Moody's uses for purposes of benchmarking executive compensation. See Moody's 2016 Form 10-K, supra note 27, at 14, 37; NYU Global Datasets, N.Y.U. STERN SCH. OF BUS. (Jan. 2016), http://pages.stern.nyu.edu/ adamodar/New_Home_Page/datafile/margin.html [https://perma. cc/Y6FV-C5UT]; Moody's Corp., Schedule 14A Information 40 (Mar. 2, 2016); Mary Ellen Biery, These Industries Generate the Highest Profit Margins, ForBes (Sept. 6, 2015), http://www.forbes.com/sites/sageworks/2015/09/06/these-industries-generate-the-highest-profitmargins/\#6a4c52c264ac [https://perma.cc/P4MX-8AFD] (finding lower profit margins in other industries). This Article discusses the profitability, power, and influence of Moody's and S\&P in detail in Part $\mathrm{I}$.

29. See Lawrence J. White, The Credit Rating Agencies: An Analysis Through the Lenses of Industrial Organization, Finance, and Regulation, 21 PAC. ECON. REV. 202, 202 (2016) (documenting the credit rating agency oligopoly).

30. See Valentin Dimitrov, Darius Palia \& Leo Tang, Impact of the Dodd-Frank Act on Credit Ratings, 115 J. FIN. ECON. 505, 506 (2015) (finding that after the Dodd-Frank Act, credit rating agencies issued lower ratings, gave more false warnings, and issued downgrades that were less informative); Rhee, Why Credit Rating Agencies Exist, supra note 5, at 171 (arguing that credit rating agencies produce little new information, but simply play a sorting function). As noted below, Dimitrov, Palia, \& Tang suggest that increased regulatory costs were responsible for the decline in the informativeness of ratings, a suggestion that is not uncontroversial. See infra note 85 .

31. I discussed this continuing paradox in Frank Partnoy, The Paradox of Credit Ratings, in THE ROLE OF CREDIT REPORTING SYSTEMS IN THE INTERNATIONAL ECONOMY (Richard M. Levitch, Giovanni Majnoni, \& Carmen Reinhart eds., 2002). Credit rating agencies have responded that credit ratings are correlated with actual default experience. See STANDARD AND POOR'S RATINGS SERvices, 2014 annual Global Corporate Default Study and Rating Transitions 35 
This Article makes two central contributions. First, it describes the effects of changes in credit rating regulation. Although numerous scholars criticized the rating agencies in the immediate aftermath of the financial crisis, scholarly attention to credit rating agencies has waned since this initial wave of commentary. ${ }^{32}$ In particular, no scholar has undertaken a thorough assessment of how the sweeping changes in regulation after the financial crisis have impacted the rating agencies, their methodologies, and the role they play in financial markets.

Second, this Article demonstrates that the regulatory changes have failed to address the problems generated by the proliferation of regulatory licenses. Deleting references in some statutes and regulation was a good first step. But many important institutions continue to rely mechanistically on ratings. ${ }^{33}$ Moreover, Congress did not amend-and thus did not impact - either state law or international regulation of various financial functions. After more than three decades of sustained reliance on NRSRO ratings, many institutions need guidance to be weaned off such ratings. Some regulators are working to that end, but many are not. ${ }^{34}$

The need for the next regulatory step-encouraging and facilitating reduced reliance on ratings - is consistent with theories of "stickiness" offered by behavioral law and economics scholars. ${ }^{35}$ Corporate and securities law scholars have addressed stickiness in default rules and the

(2015) (showing that lower ratings are associated with greater default vulnerability). However, it would be surprising if they were not: anyone with a Bloomberg subscription and a basic knowledge of financial statements can publish credit ratings that are correlated with defaults, simply by following market prices, reading the news, and then adjusting ratings. Scholarly efforts are more skeptical about whether credit ratings have any informational utility. See Dimitrov, Palia \& Tang, supra note 30, at 429; Mark J. Flannery, Joel F. Houston \& Frank Partnoy, Credit Default Swap Spreads as Viable Substitutes for Credit Ratings, 158 U. PA. L. REV. 2085, 2114 (2010) (documenting that credit default swap spreads incorporated information significantly more quickly than credit ratings).

32. Regulators have implored academics to address recent changes regarding credit rating agencies. See Seth Carpenter, Acting Assistant Sec'y, Dep't of the Treasury, Remarks Before the Nat'l Economists Club (Sept. 25, 2015), in Treas. JL-180, at 1.

33. See infra Part I.

34. Dodd-Frank's charge that regulators should protect users of credit ratings arguably includes authority to ensure implementation of the statutory directive to remove references to credit ratings. See Dodd-Frank Act $\S 932$.

35. Of particular relevance is scholarship exploring the extent to which contract default rules can be sticky, particularly when use is widespread, as in boilerplate. See Ian Ayres, Menus Matter, 73 U. CHI. L. REV. 3, 6 (2006); Ian Ayres, Regulating Opt-Out: An Economic Theory of Altering Rules, 121 Yale L.J. 2032 (2012); Omni Ben-Shahar \& John A. E. Pottow, On the Stickiness of Default Rules, 33 FLA. ST. L. REV. 651 (2006); Jason Scott Johnston, Strategic Bargaining and the Economic Theory of Contract Default Rules, 100 YALE L.J. 615 (1990); Michael Klausner, Corporations, Corporate Law, and Networks of Contracts, 81 VA. L. REV. 757 (1995). 
potential for path dependence. ${ }^{36}$ Relatedly, other scholars have assessed the potential benefits of "temporary legislation" or "sunset clauses," in substantial part to force regulators to justify rules and avoid regulatory

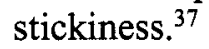

This Article contributes to these literatures by demonstrating how regulatory reliance can be a source of stickiness, meaning that once market participants have begun relying on a particular measure, it is difficult and costly for them to stop. The use of letter ratings to assess bond credit during the early twentieth century was facilitated by path dependence and the simplicity of a coordinated solution, not unlike the adoption of technology standards generally. ${ }^{38}$ During those earlier times, any resulting inefficiencies were minor and the credit rating business was small and did not impose significant externality costs, such as systemic risk. Before the mid-1970s, credit ratings, like many other financial market standards, did not derive their value from regulatory reliance.

However, once regulatory references to credit ratings began to proliferate, and regulatory licenses became more common and valuable, reliance on credit ratings became far stickier. Today, this stickiness exacerbates difficulties in implementing Dodd-Frank's move away from references to ratings. Thus, this Article also contributes to the academic debate about the relationship between regulation and standard setting, and offers the stickiness of reliance on credit ratings as a cautionary example for other regulated areas. ${ }^{39}$

36. See Frank H. Easterbrook \& Daniel R. Fischel, THe Economic Structure of CORPORATE LAW (1991); Steven M. Bainbridge, Insider Trading Regulation: The Path Dependent Choice Between Property Rights and Securities Fraud, 52 SMU L. REV. 1589 (1999); Lucian Bebchuk, The Debate on Contractual Freedom in Corporate Law, 89 CoLUM. L. REV. 1395, 140815 (1989); Henry Hansmann \& Reinier Kraakman, The End of History in Corporate Law, 89 GEO. L.J. 439, 444-49 (2001); Brett McDonnell, Sticky Defaults and Altering Rules in Corporate Law, 60 SMU L. REV. 383 (2007).

37. See Jacob Gerson, Temporary Legislation, 74 U. CHI. L. REV. 247 (2007); Robert W. Hahn, Achieving Real Regulatory Reform, 1997 U. CHI. LEGAL F. 143, 156 (1997); Jeffrey J. Rachlinski \& Cynthia R. Farina, New Theories of the Regulatory State: Cognitive Psychology and Optimal Government Design, 87 CORNELL L. REV. 549, 605 (2002).

38. See Frank Partnoy, Second-Order Benefits from Standards, 48 B.C. L. REV. 169 (2007) (assessing how private parties can benefit from the adoption of standards in various areas, including the early twentieth century adoption of standards related to credit ratings and Underwriters Laboratory assessments).

39. See, e.g., Lawrence A. Cunningham, Private Standards in Public Law: Copyright, Lawmaking and the Case of Accounting, $104 \mathrm{MICH}$. L. REV. 291 (2005); Jody Freeman, The Private Role in Public Governance, 75 N.Y.U. L. REV. 543 (2000); Orly Lobel, The Renew Deal: The Fall of Regulation and the Rise of Governance in Contemporary Thought, 89 MINN. L. REV. 342 (2004); Frank Partnoy, Second-Order Benefits from Standards, 48 B.C. L. REV, 169 (2007); Sidney A. 
Specifically, this Article assesses these issues in three major areas of credit rating agency reform. Part I assesses efforts to remove regulatory licenses. Part II examines the attempts at enhanced oversight, including recent examinations by the new Office of Credit Ratings and findings of ongoing rating agency failures. Part III addresses recent changes in accountability, particularly through government and private litigation.

In each of these three areas-regulatory licenses, oversight, and accountability-I show that reforms have been inadequate. ${ }^{40}$ Regulatory licenses persist. Office of Credit Ratings (OCR) oversight has not resulted in any meaningful sanctions and OCR findings are mostly anonymous, so rating agencies do not even suffer reputational costs. Government settlements with S\&P in 2015 and Moody's in 2017 had little impact, and the rating agencies have hampered future enforcement through lobbying efforts that led to the gutting of two important DoddFrank reforms: the provision for liability under section 11 of the Securities Act of 1933 and the removal of the rating agency exemption under Regulation FD. ${ }^{41}$ In each instance, Congress passed an important statutory provision, only to have it undone. ${ }^{42}$ This Article argues that any substantive reform of credit rating agencies should begin in these areas, by implementing the express will of Congress.

In Part IV, the Article turns to the effects of these regulatory failures on the credit rating agencies' methodologies. The literature has largely ignored the specifics of rating agency methodologies, even though flawed methodologies were central in the financial crisis. My goal in this Part is to show how current rating methodologies remain flawed, overly simplistic, nonsensical, and arbitrarily subjective. The Article also examines two methodological approaches in detail, the treatment of diversification and of investment holding companies (IHCs), where

Shapiro, Outsourcing Government Regulation, 53 DUKE L.J. 389 (2003). The regulatory reaction to, and the absence of judicial review of, federal credit rating agency reforms are consistent with the observation that much administrative practice falls far short of the goals of "transparency, rule of law, and reasoned implementation of statutory mandates." Daniel A. Farber \& Anne Joseph O'Connell, The Lost World of Administrative Law, 92 TEX. L. REV. 1137, 1140 (2014).

40. The regulation of credit rating agencies is thus consistent with extant theories about the problems of both market failure and regulatory failure. See Joseph Stiglitz, Regulation and Failure, in New Perspectives on Regulation 17 (David A. Moss \& John A. Cisternino eds., 2009); Stephen J. Choi \& Adam C. Pritchard, Behavioral Economics and the SEC, 56 STAN. L. REV. 1,

20-21 (2003) (discussing regulatory failure at the SEC); Hillary A. Sale, Judging Heuristics, 35 U.C. DAVIS L. REV. 903, 904 (2002) (discussing regulatory failure among judges).

41. See infra sections III.A-B.

42. See id. 
revised approaches make little sense and fail to generate useful information.

It is difficult to anticipate when an area of credit ratings might prove to be as inaccurate as those that precipitated the financial crisis. Yet given continuing methodological flaws, another instance of widespread credit rating agency mistakes seems inevitable. If the markets experience another crisis related to credit ratings, and ratings prove again to have been "garbage out," then during any potential future regulatory response it will be important to understand more clearly the role of the "garbage in." 43

By exposing the major credit rating agencies' flawed methodologies, this Article hopes to encourage market participants to look elsewhere in their assessments of credit risk and to prod regulators to help them do so. Leading institutional investors and analysts of corporate bond credit risk have long employed far more subtle and sophisticated methods than those reflected in the credit rating agencies' methodologies. ${ }^{44} \mathrm{~A}$ modern sophisticated assessment of corporate bond credit risk could include not only analysis of market prices and related variables, ${ }^{45}$ but also optionadjusted valuation and risk assessment, simulations of income statement variables, stress tests of risk factors, and detailed consideration of recovery rates. ${ }^{46}$ Market participants should rely less on credit ratings and more on fundamental factors, such as market measures of credit risk, financial measures of leverage and profitability, accounting measures of earnings and cash flow, and worst-case scenario analysis with respect to both individual credits and portfolios.

Fundamentally, unwarranted and mechanistic reliance is what is still wrong with credit ratings. This Article suggests some regulatory reforms

43. In the aftermath of the 2007-08 financial crisis, it was difficult for regulators and commentators to ascertain the details associated with the methodologies behind the high credit ratings on mortgage-related fixed income instruments. It is my hope that, if there is another crisis, scholars will be able to look to this Article for a description of the relevant methodologies in use today.

44. See Howe, supra note 10, at 343-71 (describing Pacific Investment Management Company's approach, including a detailed and subtle analysis of eight industry consideration variables, various approaches to financial ratio analyses, analyses of the components of a company's return on equity, and consideration of non-financial factors such as management, foreign exposure, and indenture provisions).

45. See Kamakura Credit Risk, supra note 10 (describing the factors in Kamakura's proprietary models for assessing corporate credit risk).

46. See Rainer Jankowitsch, Florian Nagler \& Marti G. Subrahmanyam, The Determinants of Recovery Rates in the US Corporate Bond Market, 114 J. FIN. ECON. 155, 156 (2014) (considering the impact of bond characteristics, firm fundamentals, macroeconomic variables, and various liquidity measures on corporate bond recovery rates). 
to remedy this ongoing problem. Ultimately, both regulators and investors should stop relying extensively on credit ratings.

\section{THE LEGACY OF REGULATORY LICENSES}

This Article begins by assessing the stickiness of regulatory licenses despite reform efforts. It traces the development of these reforms and documents the continuing reliance on credit ratings even after the reforms.

In the aftermath of the financial crisis, Congress adopted a proposal to remove regulatory licenses from federal law. Specifically, section 939A of Dodd-Frank provided for the removal of NRSRO references from both statutes and regulations. ${ }^{47}$

Some regulators have not only removed NRSRO references but have also undertaken to help transition regulated institutions away from reliance on ratings. However, very few attempts at regulatory reform have been successful, illustrating the stickiness of regulatory licenses-licenses that entitle market participants to be in compliance with regulation. The best example of a successful attempt at reform is efforts by bank regulators. The Federal Deposit Insurance Corporation (FDIC) has provided guidance to regulated banks to help them transition away from relying on NRSRO ratings ${ }^{48}$ and instead perform due diligence to determine whether issuers of debt securities have "an adequate capacity to meet financial commitments under the security for the projected life of the asset or exposure." 49

The FDIC advises that, in order to make this assessment, banks should determine that "the risk of default by the obligor is low" by performing due diligence, with the depth of the due diligence being "a function of the security's credit quality, the complexity of the structure, and the size of the investment." ${ }^{50}$ Banks may use credit ratings in their due diligence, but they also must consider and document other factors;

47. Dodd-Frank Act $\S 939 A(a)(1)-(2)$, (b).

48. See Office of the Comptroller of the Currency, Alternatives to the Use of External Credit Ratings in the Regulations of the OCC, 77 Fed. Reg. 35253-59 (June 13, 2012) (to be codified at 12 C.F.R. pts. 1, 5, 16, 28, and 160); Fed. Deposit Ins. Corp., Revised Standards of Creditworthiness for Investment Securities, Financial Institution Letter FIL-48-201 (Nov. 16, 2012); Alternatives to the Use of External Credit Ratings in the Regulations of the OCC, OCC Bulletin 2012-18 [75 Fed. Reg. 49,423] (June 26, 2012) (to be codified at 12 C.F.R. pts. 1, 6, and 28).

49. See Investment Securities: New Rules for Assessing Credit Risk, Federal Deposit Insurance Corporation, 2014 FDIC Chicago Region Regulatory Conference Call Series, FDIC 6 (Apr. 24, 2014), https://www.fdic.gov/news/conferences/chicago_region/2014-04-24.pdf [https://perma.cc/ 7RV3-WAMJ].

50. See id. at 6, 7 . 
they may outsource data and analysis, but must make the final decision. ${ }^{51}$ The FDIC cites market-based measures of credit risk as one source of data. ${ }^{52}$

Similarly, the National Credit Union Administration (NCUA) Office of Examination and Insurance published guidance for credit unions transitioning away from reliance on NRSRO ratings. ${ }^{53}$ Regulators recommended that credit unions consider several alternatives to credit ratings: credit spreads, ${ }^{54}$ securities-related research, internal or external credit assessments, default statistics, inclusion on an index, priorities, and enhancements, and various market data, including price, yield, and/or volume. 55 The guidance notes that ratings may be used to supplement a credit union's analysis but should not be the sole basis for determining the suitability of investments. ${ }^{56}$ NCUA regulators understand the implicit requirement that they not only remove references to ratings but assist with the transition away from mechanistic reliance. ${ }^{57}$ These regulatory efforts recognize that NRSRO ratings lack informational content, and they embrace more information-rich measures, such as market measures of credit risk, along with fundamental analyses. ${ }^{58}$

51. See id. at 8 .

52. See id. at 14-18. Likewise, the Federal Reserve Board of Governors also has confronted the stickiness of community bank reliance on NRSRO ratings, explaining in newsletters how banks can rely on market data in their credit assessments. See Christopher McBride, Investing in Securities Without Relying on External Credit Ratings, Community Banking Connections, FED. RESERVE SYS. (2013), https://www.communitybankingconnections.org/articles/2013/Q2/Investing-in-SecuritiesWithout-Relying-on-External-Credit-Ratings [https://perma.cc/R8BD-RSLU].

53. Regulators warned that many corporate credit unions had "placed undue reliance on NRSRO credit ratings by failing to perform an independent analysis of the credit-worthiness of an investment." Supervisory Letter from the Nat'l Credit Union Admin. Office of Examination and Ins., to All Field Staff, Investing in Securities Without Reliance on Nationally Recognized Statistical Rating Organizations (NRSRO) Ratings 2 (June 11, 2013).

54. A credit spread is the difference between the yield on a bond and the risk-free rate, and represents a market-based reflection of the credit risk associated with a debt security. See Flannery, Houston \& Partnoy, Viable Substitutes, supra note 31, at 2087.

55. See Supervisory Letter from the NCUA, supra note 53, at 3-4.

56. See id. at 3-6 (noting that the depth of the due diligence should be a function of the security's credit quality, the complexity of the structure, and the size of the investment).

57. See id. at 8 ("The removal of credit ratings from regulations compels NCUA to reiterate the importance of having a sound due diligence process within the credit union to manage investment credit risk.").

58. For example, Pacific Investment Management Co., known as PIMCO, has taken a more sophisticated approach to investing in bonds, advocating a range of strategies relating to fundamental "bottom up" credit analysis; macroeconomic, sector, and market analysis; duration management; yield curve positioning; and roll down, as well as the use of derivatives and various risk management techniques. See Everything You Need to Know About Bonds, PIMCO (2017), 
Unfortunately, these regulatory efforts are exceptional, and section 939A has not accomplished its objectives for several reasons. First, and most basically, although Dodd-Frank mandated the removal of regulatory licenses, it did not address all of them. Federal law still includes references to the "investment grade" credit rating delineation. ${ }^{59}$ For example, rules governing U.S. highway infrastructure finance include such "regulatory licenses" based on S\&P and Moody's nomenclature (though without the term NRSRO). ${ }^{60}$ Similar requirements exist for water infrastructure finance projects. ${ }^{61}$ Indeed, numerous volumes of the U.S. Code still include references to investment-grade credit rating requirements. ${ }^{62}$

Second, and similarly, in Dodd-Frank the regulators who were charged with removing regulatory licenses did an incomplete job; many references to credit ratings remain. Consider Rule 2a-7 of the Investment Company Act of 1940, which had defined "eligible securities" for money market funds based on NRSRO ratings. ${ }^{63}$ Rule 2a-7 required that $97 \%$ of a fund's securities have NRSRO ratings in the top short-term

https://www.pimco.com/resources/education/everything-you-need-to-know-about-bonds [https://perma.cc/UV48-MFFQ].

59. 23 U.S.C. $\S 601(\mathrm{a})(4)(2012)$.

60. Federal law currently provides that "[t]he funding of a line of credit under this section shall be contingent on the senior obligations of the project receiving an investment-grade rating from 2 rating agencies." Id. $\S 604(\mathrm{a})(4)$. The term "investment-grade rating" is then defined as "a rating of BBB minus, Baa3, bbb minus, BBB (low), or higher assigned by a rating agency to project obligations." Id. $\S 601(\mathrm{a})(4)$; see also id. $\S 602$ (a)(2) (defining eligibility under federal programs as requiring an investment grade rating from at least two rating agencies); id. $\S 603$ (b) (providing for maximum amounts of secured loans based on investment grade ratings); id. $\S 610(\mathrm{~g})$ (providing an alternative that infrastructure banks maintain a continuing investment grade rating).

61. See 33 U.S.C. $\& 3908(a)(3)$ (2012) ("The execution of a secured loan under this section shall be contingent on receipt by the senior obligations of the project of an investment-grade rating."); id. $\S 3907(a)(1)(D)$ (requiring both preliminary opinion letters and final rating opinion letters "from at least 2 rating agencies indicating that the senior obligations of the project have an investment-grade rating"). The water infrastructure finance project requirements also are defined using the ratings symbols used by S\&P and Moody's. See id. $\S 3901$ ("The term 'investment-grade rating' means a rating of $\mathrm{BBB}$ minus, $\mathrm{Baa} 3$, bbb minus, $\mathrm{BBB}$ (low), or higher assigned by a rating agency to project obligations.").

62. Similar requirements continue to exist with respect to legislation governing railroad industry direct loans and loan guarantees, 45 U.S.C. $\$ 822(f)(3)(C)(2012)$, multi-family special affordable housing goals, 12 U.S.C. $\S 4563$ (2012), premium rate benefit valuations for the Pension Benefit Guaranty Corporation, 29 U.S.C. $\S 1306(a)(3)(E)(i v)(2012)$, rural electrification and telephone service bond guarantees, 7 U.S.C. $\S 940 \mathrm{c}-1(\mathrm{~b})(3)(\mathrm{B})(2012)$, the privatization of the college construction loan insurance association, 20 U.S.C. $\$ 1155(\mathrm{~b})(4)(2012)$, and limitations on the termination of single-employer retirement plans, 29 U.S.C. $\S 1341$ (b)(5)(B)(i) (2012).

63. See Removal of Certain References to Credit Ratings and Amendment to the Issuer Diversification Requirement in the Money Market Fund Rule, Investment Company Release No. IC-31828, 17 C.F.R. $\S \S 270,274$ (Oct. 26, 2015). 
credit quality category. ${ }^{64}$ Dodd-Frank tasked the SEC with proposing and implementing a new regime for "eligible securities" under Rule 2a7.65

In 2014, the SEC replaced the NRSRO-focused language in Rule 2a-7 with a general requirement that the boards of money market funds determine that a security "presents minimal credit risks" in order to be deemed eligible. ${ }^{66}$ Revised rules require that boards determine that a security "presents minimal credit risks" by analyzing four factors related to the issuer or guarantor: (1) its financial condition, (2) its sources of liquidity, (3) its ability to react to events, including ability to repay debt in a highly adverse situation, and (4) its competitive strength and position with the industry and the economy overall. ${ }^{67}$

However, credit ratings did not entirely disappear from the Rule 2a-7 regulatory standard. For example, although credit ratings were not explicitly included in Rule 2a-7's definitions, the SEC adopted a new requirement that a fund's board disclose NRSRO ratings on Form NMFP under certain circumstances. ${ }^{68}$

Credit ratings continue to play a significant role in other federal regulation, in a wide range of areas, and regulators continue to adopt new regulations that depend on ratings. The 2016 Federal Reserve banking rules governing the Term Asset-Backed Securities Loan Facility (TALF) provided that credit collateral requirements are based, in part, on whether collateral "[i]s registered with the Securities and Exchange Commission as a Nationally Recognized Statistical Rating Organization for issuers of asset-backed securities." ${ }^{\prime 9}$ In 2016, the Federal Communications Commission adopted new rules that included a cutoff for letter of credit requirements based on whether the relevant entity had "maintain[ed] a credit rating of BBB- or better from Standard \& Poor's (or the equivalent from a nationally-recognized credit rating agency)." Federal transportation regulations governing applications for financial assistance state that "[w]here an [a]pplicant has received a recent credit rating from one or more nationally recognized rating agencies, that

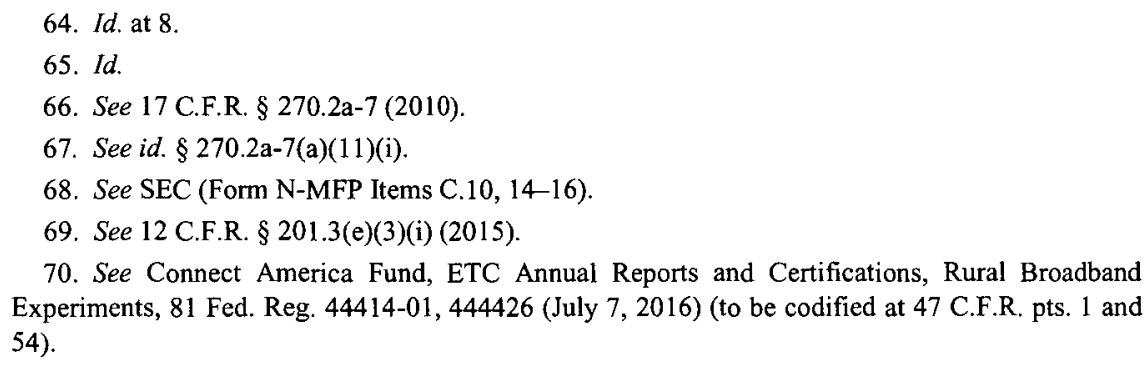


rating will be used to estimate the credit risk." ${ }^{11}$ Even the SEC has been a victim of the stickiness associated with regulatory licenses, occasionally continuing to reference NRSROs after Dodd-Frank. ${ }^{72}$ Thus, the regulatory addiction to reliance on credit ratings continues unabated.

Third, the Dodd-Frank mandate was limited to federal law. References to credit ratings remain embedded in much of the international regulatory regime, including Basel bank capital requirements, and regulators outside the U.S. continue to rely on credit ratings in various ways. ${ }^{73}$ Likewise, Dodd-Frank did not require removal of references to ratings in state legislation and regulation, much of which continues to reference NRSROs. ${ }^{74}$

As a result, reliance on NRSRO ratings has been sticky even among the largest and most sophisticated global financial institutions. Some financial advisors, which are required to reduce reliance on NRSRO ratings, nevertheless recommend that their clients adopt such reliance in their investment guidelines. ${ }^{75}$ Portions of the shadow financial system also still depend on credit ratings. According to global surveys of repo market participants, NRSRO ratings continue to be important and market participants note that the requirement of a AAA rating persists. ${ }^{76}$ It remains unclear the extent to which global bank capital requirements ultimately will depend on credit ratings, although international banking

71. See 49 C.F.R. $\S 260.17$ (b)(1) (2016).

72. See Staff Responses to Questions About Money Market Fund Reform, SEC (Aug. 7, 2012), https://www.sec.gov/divisions/investment/guidance/mmfreform-imqa.htm [https://perma.cc/H97PUTBX] (referencing NRSRO requirement to disclose "Designated NRSROs").

73. For example, European financial institutions resisted efforts by European regulators to remove references to credit ratings. See Norbert J. Gaillard, Coping with Reliance on Credit Ratings, 35 BANKING \& Fin. SERVS. POL'Y REP. 12 (2016) (comparing U.S. and European approaches to regulatory reliance).

74. See, e.g., CAL. Gov. CODE $\S 15819.4$ (a) (West 2017) (requiring that certain financing instruments "shall not be sold by the Treasurer unless, at the time ... they are rated in the highest short-term rating category by a nationally recognized rating service").

75. Wells Fargo Asset Management recommends to its institutional clients: "[i]t is important to be specific about ratings. In particular, credit limits should specify the plus and minus tiers, such as whether a minimum rating of A means A- or only A." See A PRIMER ON CASH INVESTMENT POLICY STATEMENTS, WELLS FARGO ASSET MGMT. (Dec. 2015), https://www.wellsfargofunds.com/assets/ $\mathrm{pdf} / \mathrm{fmg} / \mathrm{icm} /$ primer-cips.pdf [https://perma.cc/VTX8-U5HH].

76. See Frequently ASKed Questions on Repo, InT'L Cap. MKT. Ass'N 8 (Feb. 2013), http://www.treasurers.org/ACTmedia/Repo_faqs.pdf [https://perma.cc/E2SK-S5DU] ("A AAArating is required by most investors" for asset-backed securities); $i d$. (noting the decline in the use of mortgage-backed securities as repo collateral after the financial crisis, but stating that "[t]o be widely accepted as collateral, these issues need to be AAA- rated"). 
regulators recently have indicated a willingness to retain some reliance on credit ratings. ${ }^{77}$

Fourth, and perhaps most important, investor reliance on credit ratings continues, and the legacy of four decades of regulatory licenses persists, with many institutions continuing to look to credit ratings for various purposes. Notwithstanding efforts by some regulators, mechanistic reliance on NRSRO ratings continues in many market sectors, reflecting the stickiness of regulatory licenses.

Although banks and credit unions have made some progress in reducing regulatory reliance, several other categories of institutional investors continue to rely mechanistically on NRSRO ratings, including states, ${ }^{78}$ counties, ${ }^{79}$ cities,${ }^{80}$ municipal organizations, ${ }^{81}$ universities,${ }^{82}$ and

77. See Basel III Document: Revisions to the Securitization Framework, Basel Comm. ON BANKING SUPERVISION 4 (July 2016), http://www.bis.org/bcbs/publ/d374.pdf [https://perma.cc/ 3T9L-FQY4] (suggesting adjustments to risk weights of mezzanine tranches of securitized debt instruments based on external credit ratings).

78. On July 28, 2016, the state of West Virginia adopted an investment policy that relies explicitly and mechanistically on NRSRO ratings with respect to numerous investment types, including asset-backed commercial paper. See W. VA. BOARD OF TREASURY, INVESTMENT POLICY 8 (July 28, 2016), www.wvtreasury.com/RFP-RFQ/FileId/5628 [https://perma.cc/48RH-LN9P] ("Any asset backed commercial paper with one of the two highest short term credit ratings by a NRSRO (e.g., rated A-1/P-1/F-1 or better)."); id. at 8-10 (relying on NRSRO ratings with respect to several categories of debt instruments, including corporate debt, mutual funds, and mortgagebacked securities). Other states have similar provisions in their investment guidelines. See investment Policy: General Portfolio, St. of Nev. Off. of the St. Treasurer 5-9 (Jun. 2012), https://nevadatreasurer.gov/documents/investment/generalfund-investmentpolicy.pdf [https:// perma.cc/7SV6-2S4E]; State Statement of InVESTMent Policy, Treasurer of St. OF OHio ST. TREASURY 1-9 (July 5, 2017).

79. On March 29, 2016, the County of Los Angeles adopted an investment policy with a detailed schedule of minimum NRSRO ratings for various permitted investments, including corporate notes, asset backed-securities, and floating-rate notes. See TREASURER AND TAX COLLECTOR INVESTMENT POLICY, CTY. OF L.A. 15-17 (Mar. 29, 2016), https://ttc.lacounty.gov/Proptax/docs/Investment\%20 Policies.pdf [https://perma.cc/WQ2G-YZWV]; see also id. at 10 (requiring that commercial paper be "' of prime' quality of the highest ranking or of the highest letter and number rating as provided for by a NRSRO").

80. On December 15, 2015, the City of Riverside, a municipality that suffered financial distressed due in part to the role of NRSROs during the financial crisis, adopted a Statement of Investment Policy that relied explicitly and mechanistically on NRSRO ratings. See City of El Cajon Investment Policy, CITY of EL CAJON 5-6 (Sept. 2016), http://cityofelcajon.us/home/ showdocument 7 id $=4836$ [https://perma.cc/6KXY-5Z73] (requiring minimum NRSRO ratings for numerous categories of investments, including, for example, for asset-backed securities that '[p]urchases are limited to securities rated at least in the ' $\mathrm{AA}$ ' category, or its equivalent, by a NRSRO").

81. As of January 1, 2017, the California Debt and Investment Advisory Commission adopted an investment policy that relies explicitly and mechanistically on NRSRO ratings with respect to numerous investment types, including commercial paper. LOCAL AGENCY INVESTMENT Guidelines, Cal. DeBt \& INV. ADVISORY COMM'N 14 (Jan. 1, 2007), http://www.treasurer. ca.gov/cdiac/LAIG/guideline.pdf [https:/perma.cc/U5WG-GVCM] (requiring the "[h]ighest letter 
pension funds. ${ }^{83}$ According to one recent survey of corporate treasury investment policy statements, explicit reliance on credit ratings by Moody's, S\&P, and Fitch actually increased after the financial crisis, and the vast majority of corporate treasury policies require a minimum rating of single-A. ${ }^{84}$

Dodd-Frank was an attempt to undo the legacy of regulatory licenses, as shown by the efforts to change bank regulation described above. However, the attempt appears not to have changed the underlying economics or incentives of the major NRSROs. As noted above, scholars have found that the informational content of credit ratings declined after Dodd-Frank. ${ }^{85}$ It is difficult to isolate causality, and event-study analysis

and number rating" by an NRSRO); see also id. (requiring AA rating for mortgage-backed securities and an A rating for medium-term notes); UNION SANITARY DISTRICT POLICY: INVESTMENT POLICY, UNION CITY, CAL. (Jan. 1, 2017) https://www.unionsanitary.com/images/ documents/2030_Investment_Policy.pdf [https://perma.cc/R5TQ-BFTQ] (adopting similar NRSROrelated requirements)

82. The University of Miami's short-term investment policy relies explicitly on NRSRO ratings for several categories of investments, including corporate bonds (" $[F]$ or maturities greater than one year, fixed and floating rate of at least A-/A3 or higher by at least one NRSRO") and money-market instruments ("Investments must have a short-term rating of at least A-1/P-1 or the equivalent or a long-term rating of at least A-/A3 or the equivalent by at least one" NRSRO). SHORT-TERM InVESTMENT Policy: Working CAPITAL, U. OF Miami (Oct. 2014) (adopting similar NRSROrelated requirements).

83. The California Public Employees' Retirement System, known as CalPERS, actually increased its reliance on NRSRO ratings in late 2015, adding a provision limiting authorized CalPERS external credit rating agencies to Moody's, S\&P, and Fitch, and adopting credit rating portfolio limits that mechanistically rely on those three NRSROs. See, e.g., CALIFORNIA PUBLIC EMPLOYEes' ReTIREMENT SYSTEM: INVESTMENT POLICY FOR GLOBAL FIXED INCOME PROGRAM 6 (Nov. 16, 2015), https://www.calpers.ca.gov/docs/board-agendas/201511/invest/item06a-01.pdf [https://perma.cc/J3JZ-S9JN] ("Credit Rating Portfolio Limits - The average credit quality of the Program's portfolio shall be 'single-A' long-term credit rating designation (A2 by Moody's, A by S\&P and A by Fitch).").

84. See Shaping Investment Policies for a Safer Cash Portfolio, Cap. advisors GrP. (June 2012), https://capitaladvisors.com/wp-content/uploads/2016/12/Shaping-Investment-Policiesfor-a-Safer-Cash-Portfolio.pdf [https://perma.cc/D97M-DG28] (reporting that "there was a slight uptick in investment policies requiring a minimum credit rating of AA or AAA today versus in 2009 , although the vast majority of Capital Advisors Group's clients continue to require a minimum rating of A").

85. See Dimitrov, Palia \& Tang, supra note 30, at 429. Interestingly, some commentators have suggested that the reason credit ratings became less informative after Dodd-Frank was greater regulatory scrutiny. See id. If this suggestion were correct, additional increased regulatory costs, including costs arising from some of the proposals advanced in this Article, in particular relating to section 11 and Regulation FD, might risk making credit ratings less informative (and, conversely, that proposals here reducing regulatory costs might make credit ratings more informative). However, an alternative interpretation is that the recent declining informativeness of credit ratings was not caused by increased regulatory costs. In any event, as noted below, the Congressional proposals related to section 11 and Regulation FD arguably would generate socially valuable net results. 
of the effects of credit rating reforms would be difficult. ${ }^{86}$ But one nevertheless can observe certain facts regarding the post-reform performance of the major credit rating agencies. Available metrics show strong financial performance of major credit rating agencies. ${ }^{87}$

Moody's is the only free-standing credit rating agency with publicly traded shares. From the 2008 bankruptcy of Lehman Brothers through January 2017 , Moody's common shares were up approximately $180 \%$, compared to a roughly $81 \%$ gain for the S\&P 500 during the same period. ${ }^{88}$ From July 21, 2010, when President Barack Obama signed Dodd-Frank, through January 2017, Moody's shares gained about 355\%, while the S\&P 500 gained about $112 \% .{ }^{89}$ As of January 2017, Moody's market capitalization was nearly $\$ 20$ billion..$^{90}$

Moody's remarkable profitability sustains a massive organization. As of December 31, 2015, Moody's maintained approximately 10,400 fulltime equivalent employees. ${ }^{91}$ At the same time, Moody's operating margins were $42 \% .{ }^{92}$ Moody's operating margins were higher than those in any sector of the U.S. economy measured by financial economists, including the peer group Moody's uses for purposes of benchmarking executive compensation..$^{93}$ This performance is stunning.

86. Credit rating agency reforms do not have an obvious starting point. Moreover, most NRSROs are not publicly traded, and there is little public information about changes in their ratings or performance. Scholars have criticized event studies in areas that involve far more precision than would be possible studying credit rating agency reforms. See Jill E. Fisch, Jonah B. Gelbach \& Jonathan Klick, The Logic and Limits of Event Studies in Securities Fraud Litigation, TEX. L. REV. (forthcoming 2018) (on file with author) (highlighting the limitations of event studies in securities litigation).

87. In 2011, Moody's and S\&P each disclosed receiving more than one million dollars of ratings revenue per analyst. See S\&P, Moody's Boosting Rating Fees Faster Than Inflation, FIN. POST, (Nov. 15, 2011) http://business.financialpost.com/news/economy/sp-moodys-boosting-rating-feesfaster-than-inflation [https://perma.cc/4N9G-H3ZR].

88. On September 15,2008 , the closing price of MCO was 36.14 and the closing price of ${ }^{\wedge}$ GSPC was 1255.08; on January 20, 2017, these closing prices were 101.02 and 2,271.31, respectively. See YAHOO! FIN., https://finance.yahoo.com/quote/MCO/history?p=MCO [https://perma.cc/GUE5-9NCC].

89. On July 21,2010 , the closing price of MCO was 22.18 and the closing price of ${ }^{\wedge} \mathrm{GSPC}$ was 1,069.59. See YAHOO! FIN., https://finance.yahoo.com/quote/\%5EGSPC/history?p=\%5EGSPC [https://perma.cc/RNL3-RSVW].

90. See Moody's Corporation, YAHOO! FIN., http://finance.yahoo.com/quote/MCO?p=MCO [https://perma.cc/GUE5-9NCC] (showing $\$ 19.3$ billion market capitalization as of January 21 , 2017).

91. See Moody's 2016 Form 10-K, supra note 27, at 14.

92. See id. at 37.

93. See NYU Global Datasets: Margins by Sector (US), N.Y.U. STERN SCH. OF BUS. (Jan. 2016), http://pages.stem.nyu.edu/ adamodar/New_Home_Page/datafile/margin.html [https://perma.cc/QD 6R-NHNY]; Moody's Corp., Schedule 14A Information 40 (Mar. 2, 2016); Mary Ellen Biery, These 
S\&P Global, Inc. (SPGI), the parent company of S\&P Global Ratings, includes other businesses, making it difficult to isolate the performance of the ratings business. Nevertheless, it appears that S\&P's performance has been similar to that of Moody's. SPGI had a market capitalization of approximately thirty billion dollars as of January $2017,{ }^{94}$ and S\&P Global Ratings contributed more than half of that parent's operating profit during 2015..$^{95}$

Sophisticated investors recognize the oligopoly power and high profit margins associated with the credit rating industry, and they continue to maintain large ownership stakes of the major credit rating agencies. ${ }^{96}$ Interestingly, there is some evidence that the ownership interests of credit rating agencies generate indirect benefits as well: one study has found that Moody's ratings of bonds issued by firms that were important investees of its two significant shareholders (Berkshire Hathaway and Davis Selected Advisors) were more favorable than comparable ratings issued by S\&P and Fitch ${ }^{97}$ The same research also found that S\&P had more favorable ratings of bonds issued by the owners of its parent, McGraw Hill. ${ }^{98}$ These findings suggest that reforms have not negatively impacted the credit rating business.

The ongoing profitability and market value of Moody's and S\&P supports a conclusion that regulatory licenses have been sticky and persistent. The Dodd-Frank attempts at removal of regulatory references to NRSRO ratings have not changed the oligopolistic structure of the credit rating industry. Moody's and S\&P continue to dominate and profit, notwithstanding the continuing uninformative nature of their ratings.

Industries Generate the Highest Profit Margins, FORBES (Sept. 6, 2015), http://www.forbes.com /sites/sageworks/2015/09/06/these-industries-generate-the-highest-profit-margins/\#6a4c52c264ac [https://perma.cc/J3TD-RX4R].

94. See S\&P Global Inc., YAHOO! FIN., http:/finance.yahoo.com/quote/SPGV?p=SPGI [https:/perma.cc/983B-C8FR] ( $\$ 30.1$ billion market capitalization as of January 20, 2017).

95. See S\&P Global Inc., Annual Report (Form 10-K) (Feb. 12, 2016).

96. For example, Berkshire Hathaway held $12.9 \%$ of Moody's shares as of January 2017. See Moody's Corporation, YAHOO! FIN., http://inance.yahoo.com/quote/MCO/holders?p=MCO [https://perma.cc/3V6A-GP3P]

97. See Simi Kedia, Shivaram Rajgopal, \& Xing (Alex) Zhou, Large Shareholders and Credit Ratings, J. FIN. ECON. (forthcoming 2017) (on file with author).

98. See id. 


\section{OVERSIGHT}

In addition to the Dodd-Frank provisions, attempting to remove regulatory licenses, the statute also included several new oversight provisions. Unfortunately, their effect has been minimal and in some cases counterproductive. The lack of oversight leaves credit rating agencies largely unchecked.

\section{A. The Office of Credit Ratings}

Dodd-Frank amended section 15E of the Securities Exchange Act of 1934 to enhance the regulation, oversight, and transparency of NRSROs. ${ }^{99}$ The most significant oversight change was a new office within the SEC: the Office of Credit Ratings. The OCR assists the SEC in its major goals - protecting investors; promoting capital formation; and maintaining fair, orderly, and efficient markets-by overseeing NRSROs. ${ }^{100}$ Section 932 of Dodd-Frank imposed new reporting, disclosure, and examination requirements on NRSROs and mandated that the OCR would implement them. ${ }^{101}$

Since its creation in June 2012, the OCR has had broad responsibility for administering SEC rules, monitoring NRSRO practices, conducting compliance examinations, protecting users of credit ratings, promoting accuracy of credit ratings, monitoring conflicts of interest, and helping to ensure greater disclosure related to ratings. ${ }^{102}$

As of early 2017, ten credit rating agencies were registered as NRSROs. ${ }^{103}$ Moody's and S\&P dominate the market; Fitch is also a significant player, but the other seven credit rating agencies are smaller and the OCR explicitly describes them as "smaller NRSRO[s]."104

99. See Dodd-Frank Act $\S 932$.

100. Some smaller credit rating firms are not NRSROs, but they are not significant from an economic or regulatory perspective.

101. See id.

102. See OfFICE OF CREDIT RATINGS, SEC, https://www.sec.gov/ocr [https:/perma.cc/LLS4YKPP]. The OCR is located in New York and Washington, D.C. and is staffed with examiners, attorneys, and accountants with expertise in structured finance, corporate finance, municipal finance, financial institutions, insurance companies, and credit rating agencies.

103. See id. (orders granting registration to A.M. Best Co., Inc.; DBRS, Inc.; Egan-Jones Rating Co.; Fitch Ratings, Inc.; HR Ratings de México, S.A. de C.V., Japan Credit Rating Agency, Ltd.; Kroll Bond Rating Agency, Inc.; Moody's Investors Service, Inc.; Morningstar Credit Ratings, LLC; and S\&P Global Ratings Inc.).

104. 2015 SUMMARY REPORT OF COMMISSION STAFF'S EXAMINATION OF EACH NATIONALLY RECOGNIZED StatistiCAL RATING ORganization, SEC 8 (Dec. 2015) [hereinafter 2015 SUMMARY REPORT]. 
The OCR is required to examine each NRSRO at least annually under section 15E of the Exchange Act. ${ }^{105}$ Although the specific results are not publicly available, the OCR is required to produce an annual report summarizing its essential findings, along with summaries of any NRSRO responses to material regulatory deficiencies and whether the NRSROs have appropriately addressed the OCR's recommendations. ${ }^{106}$

\section{B. OCR Findings}

The scholarly literature has not addressed OCR's reporting, in part because, contrary to the transparency mandate of Dodd-Frank, the OCR does not identify which NRSRO was involved in each reported transgression. Instead, each violation is described only in general, often cryptic, terms, which do not permit the reader to identify which rating agency is involved. ${ }^{107}$

For example, the OCR found that on "numerous occasions" one "larger" NRSRO - presumably meaning Moody's, S\&P, or Fitch—used inaccurate and incorrect ratings methodologies for both structured finance and residential mortgage-backed security (RMBS) transactions. ${ }^{108}$ The NRSRO did not accurately code terms, and did not detect this coding mistake as part of its surveillance; the transaction was downgraded after the mistake was discovered. The mistakes resulted in "several" erroneous ratings. ${ }^{109}$ The OCR found that senior personnel changed ratings committee determinations in contravention of the NRSRO's policies and procedures; as a result, this unnamed NRSRO misapplied its rating criteria. ${ }^{10}$ These are serious and surprising

105. See id. at 5 (enumerating eight topic areas of examination).

106. Id.

107. I requested the identity of rating agencies in the OCR's reporting under the Freedom of Information Act (FOIA), but the SEC's FOIA office denied my request. The same individual acted as both FOIA Public Liaison, the designated person to assist with FOIA requests, and as FOIA Branch Chief, the person who denied my request. The SEC refused to produce information notwithstanding the FOIA Improvement Act of 2016, which states that information shall be withheld by regulators "only if the agency reasonably foresees that disclosure would harm an interest protected by an exemption or disclosure is prohibited by law." FOIA Improvement Act of 2016, Pub. L. No. 114-85; see also OIP Summary of the FOLA Improvement Act of 2016, U.S. DEP'T OF JUSTICE (Aug. 17, 2016), https://www.justice.gov/oip/oip-summary-foia-improvementact-2016 [https://perma.cc/L3TL-EJWB]. The SEC did not indicate if it made a determination that the disclosures I requested would "harm" a credit rating agency, or that it balanced any harm that might occur to one credit rating agency against the harm (or potential benefit) to another.

108. See 2015 SUMMARY REPORT, supra note 104, at 11-12.

109. Id. at 12 .

110. Id. 
allegations that resemble financial crisis-related findings that rating agencies made out-of-model upward adjustments for RMBS and CDO ratings. ${ }^{111}$

Likewise, a different "larger" NRSRO assigned "several" ratings that differed from those generated by its own quantitative model without properly documenting the rationale for the adjustment. ${ }^{12}$ This NRSRO also failed to adhere to its internal policies and procedures with respect to the withdrawal of ratings. These failures related to financial institution ratings, again echoing the rating mistakes leading up to the financial crisis. ${ }^{113}$

The OCR found that two larger NRSROs and one smaller NRSRO failed to adhere to their own policies and procedures regarding review and revision of rating methodologies, criteria, and models, and correction of errors. ${ }^{114}$ Analysts at one "larger" NRSRO learned of errors in a "substantial" number of third-party models used to determine ratings but did not analyze the impact of these errors, as required; the OCR further found substantive statements in this NRSRO's internal rating records that directly contradicted its rating publications. ${ }^{115}$ Analysts at another "larger" NRSRO made inaccurate disclosures about its rating methodologies, and did not correct an error in calculations it used to determine certain ratings, or disclose the rating implications of this error. ${ }^{116}$ At two "larger" NRSROs, rating files contained inaccurate information or were missing required documents, including "the inputs to quantitative models used to determine the rating of structured finance securities." $" 117$

OCR found similar deficiencies with respect to conflicts of interest as well. OCR staff found evidence-including emails between sales employees, analytical managers, and senior management-indicating that a "larger" NRSRO had issued an unsolicited rating of an issuer in order to capture greater market share, in contravention of its own code of conduct. ${ }^{18}$

111. See John M. Griffin \& Dragon Yongjun Tang, Did Subjectivity Play a Role in CDO Credit Ratings?, 67 J. FIN. 1293, 1307 (2009).

112. See 2015 SUMMARY REPORT, supra note 104, at 12.

113. See Flannery, Houston \& Partnoy, Viable Substitutes, supra note 31, at 2092.

114. See 2015 SUMMARY REPORT, supra note 104, at 12.

115. Id. at 13 .

116. Id.

117. Id. at 14 .

118. Id at 15 . 
In sum, NRSRO policies remain deeply flawed. ${ }^{119}$ OCR staff recommended remedial measures, but neither the NRSROs nor the involved officials were disciplined for any of these violations.

Section 932(a) of Dodd-Frank requires that the OCR make its findings available to the public in "an easily understandable format ... summarizing [its] essential findings." 120 Congress provided that the OCR investigations should be transparent. Yet the OCR hides the identity of the credit rating agencies it investigates. It is not possible to determine which NRSROs committed the various violations. ${ }^{121}$

The OCR did name S\&P in the settlement of three enforcement proceedings regarding mortgage-backed securities. The findings about S\&P's flawed assumptions, methodologies, and misstatements echo the financial crisis; they read as if nothing has changed since $2008 .{ }^{122}$ However, the vast majority of the OCR's reported transgressions do not name the wrongdoing agency.

The SEC's and OCR's ongoing transparency failures are contrary to Dodd-Frank's mandate that various information about credit ratings be published and made freely available on an easily accessible portion of each NRSRO's website. ${ }^{123}$ They also are contrary to the SEC's own 2014 release implementing its new NRSRO rules, where it repeatedly emphasized the importance of making information about each agency easily accessible. ${ }^{124}$ Indeed, the SEC used the term "easily accessible" repeatedly throughout that release to describe how individual NRSROs should make information available on an internet website. ${ }^{125}$ In these instances, the SEC's intention explicitly is to make it easier for investors to access specific information about individual NRSROs. ${ }^{126}$

This Article's oversight recommendation is straightforward. The OCR should follow Congress's mandate and include the names of NRSROs in its findings:

119. Given that two of the "larger" three credit rating agencies were involved in this conduct, one can infer that these serious problems existed at either Moody's or S\&P, or both.

120. Dodd-Frank Act $\$ 932(\mathrm{p})(3)(\mathrm{C})(\mathrm{i})$.

121. As noted above, the OCR does not specify which NRSRO committed each of the specified violations.

122. See 2015 SUMMARY REPORT supra note 104 , at 6-7.

123. See 15 U.S.C. $\S 780-7(q)(2)(D)$ (2012).

124. See National Recognized Statistical Rating Organizations, Exchange Act Release No. 34-72936, 109 SEC Docket 3429 (Oct. 14, 2014).

125. See id.

126. See id. 


\section{Limitations on the $O C R$}

Even if the OCR referenced the names of individual rating agencies, its approach still faces limitations, the most serious being its utter lack of regulatory teeth. The OCR is merely an office within the SEC, not an independent, free-standing entity with the ability to bring enforcement actions. Although SEC officials, or federal prosecutors, could bring civil or criminal enforcement actions based on OCR findings, civil actions have been infrequent and criminal actions non-existent.

Near the beginning of the 2009 Senate hearings on credit ratings, Senator Christopher Dodd, the co-author of Dodd-Frank, cited a white paper I wrote for the Council of Institutional Investors ${ }^{127}$ in which I advocated for an independent, free-standing office of credit rating agency oversight. Senator Dodd noted that one key element of the reforms I proposed was the creation of "a single independent credit rating agency oversight board," similar to the Public Company Accounting Oversight Board for accounting (PCAOB). ${ }^{128}$ However, Congress declined to adopt this proposal.

Housing the OCR within the SEC has proven to be a mistake. In recent years, the SEC has been hobbled by a massive workload in the aftermath of Dodd-Frank. Courts have criticized the SEC repeatedly on a range of issues related to its rulemakings and assessments. ${ }^{129}$ These criticisms do not necessarily apply to the OCR or its employees, but the OCR is subject to the SEC's limitations. When the OCR uncovers serious misconduct, there is no mechanism for it to engage in any serious disciplinary action.

Giving the OCR independent status would help resolve some of these issues. As William Bratton has noted, the model of delegating to an agency "works well only so long as the agency successfully resists capture by the interest of the actors it regulates." 130 Professor Bratton was writing about the PCAOB in 2003 , but his words apply equally to the OCR in 2017. In addition to independence, the OCR needs the

127. Frank Partnoy, Rethinking Regulation of Credit Rating Agencies: An Institutional Investor Perspective, (Council of Inst'l Investors, Research Paper No. 09-014, Apr. 2009).

128. See Examining Proposals to Enhance the Regulation of Credit Rating Agencies: Hearing Before the Comm. on Banking, Hous., \& Urb. Affs., 111 th Cong. 8 (2009) (statement of Sen. Chris Dodd, Chairman, S. Comm. On Banking, Hous., \& Urb. Affs.).

129. See, e.g., Abu Dhabi Commercial Bank v. Morgan Stanley \& Co., 888 F. Supp. 2d 431, 458 (S.D.N.Y. 2012) (finding that "plaintiffs have offered sufficient evidence from which a jury could infer that the ratings were both misleading and disbelieved by the Ratings Agencies when issued").

130. William W. Bratton, Enron, Sarbanes-Oxley and Accounting: Rules Versus Principles Versus Rents, 48 VILL. L. REV. 1023, 1032 (2003). 
ongoing ability and resources to engage in the same kind of meaningful oversight that has been envisioned for the PCAOB, and also the willingness to be more transparent by naming names in compliance with Dodd-Frank.

\section{ACCOUNTABILITY}

Scholars have considered the extent to which the threat of liability is a viable enforcement mechanism to promote efficiency and fairness in financial markets. ${ }^{131}$ Several commentators have addressed the extent to which "gatekeepers," including credit rating agencies, should be subject to civil liability, ${ }^{132}$ and the limitations of reputation as a constraint. ${ }^{133}$

This section contributes to this literature, focusing on Dodd-Frank credit rating accountability reforms relating to section 11 of the Securities Exchange Act of 1933 and Regulation Fair Disclosure (Regulation FD). It also discusses recent litigation against the credit rating agencies. In each case, the degree of accountability for credit rating agencies remains low. Such limited accountability contributes to the credit rating agencies' reluctance to address the major problems that contributed to the financial crisis.

\section{A. Legislation}

Dodd-Frank included several provisions designed to increase the accountability of credit rating agencies by removing the privileged treatment they had enjoyed under the securities laws. However, the SEC rejected these provisions and reinstated the privileges.

131. See Jennifer H. Arlen \& William J. Carney, Vicarious Liability for Fraud on Securities Markets: Theory and Evidence, 1992 U. ILL. L. REV. 691; John C. Coffee, Jr., Reforming the Securities Class Action: An Essay on Deterrence and Its Implementation, 106 CoLUM. L. REV. 1534 (2006); Jill E. Fisch, Confronting the Circularity Problem in Private Securities Litigation, 2009 WIS. L. REv. 333; Donald C. Langevoort, Rule 10b-5 as an Adaptive Organism, 61 FORDHAM L. REV. S7 (1993).

132. See generally John C. Coffee, Jr., Gatekeeper Failure and Reform: The Challenge of Fashioning Relevant Reforms, 84 B.U. L. REV. 301 (2004); John C. Coffee, Jr., Partnoy's Complaint: A Response, 84 B.U. L. REV. 377 (2004); Stavros Gadinis \& Colby Mangels, Collaborative Gatekeepers, 73 WASH. \& LEE L. REV. 797 (2016); Assaf Hamdani, Gatekeeper Liability, 77 S. CAL. L. REV. 53 (2003); Alessio M. Pacces \& Alessandro Romano, A Strict Liability Regime for Rating Agencies, 52 AM. BuS. L.J. 673 (2015); Frank Partnoy, Barbarians at the Gatekeepers?: A Proposal for a Modified Strict Liability Regime, 79 WASH. U. L.Q. 491 (2001).

133. See Jonathan Macey, The Value of Reputation in Corporate Finance and Investment Banking (and the Related Roles of Regulation and Market Efficiency), 22 J. APPLIED CORP. FIN. 18 (2010); Jonathan Macey, The Demise of the Reputational Model in Capital Markets: The Problem of the "Last Period Parasites," 60 SYRACUSE L. REV. 427, 432 (2010). 


\section{Section 11}

Perhaps the most significant accountability change in Dodd-Frank was repeal of Rule $436(\mathrm{~g}) .{ }^{134}$ Rule $436(\mathrm{~g})$ previously insulated NRSROs from liability as experts under section 11 of the Securities Act of 1933, which provides for liability for misstatements (such as false credit ratings) that are included or incorporated by reference in a registration statement or prospectus. Specifically, Rule 436(g) exempted NRSRO credit ratings from being deemed part of a registration statement or prospectus. ${ }^{135}$ As a result, NRSROs were not considered experts subject to section 11. Credit rating agencies that were not NRSROs remained subject to such liability, though my research has not uncovered any cases in which a non-NRSRO credit rating agency has been subject to liability under section 11.

The repeal of Rule 436(g) followed an October 2009 SEC concept release on credit ratings that included a similar repeal proposal. ${ }^{136}$ The concept release made it clear that repeal of Rule $436(\mathrm{~g})$ would significantly increase the liability risks of NRSROs. ${ }^{137}$ However, the SEC did not act on its concept release. In passing Dodd-Frank, Congress effectively made the SEC's concept release law, eliminating the differential treatment of NRSROs and non-NRSROs under section 11. During the debate about the SEC's concept release and Dodd-Frank's accountability provisions, NRSROs threatened to stop providing ratings if they were subject to liability as experts under section $11 .{ }^{138}$

After the passage of Dodd-Frank, the NRSROs followed through on their threats. They refused to provide consents with respect to new issues of investment-grade debt and asset-backed securities. ${ }^{139}$ As a result, some companies publicly stated that they would be unable to raise

134. See Dodd-Frank Act $\S 939 \mathrm{G}$.

135. 17 C.F.R. 220.436(g) (2016).

136. Concept Release on Possible Rescission of Rule 436(g) under the Securities Act of 1933, Release Nos. 33-9071, 34-60798, 96 SEC Docket 2719 (Oct. 7, 2009).

137. See id. at 3-4 ("Rescinding the exemption would cause NRSROs to be included in the liability scheme for experts set forth in Section 11 , as is currently the case for credit rating agencies that are not NRSROs."); id. at 16 (noting "we believe that rescinding Rule $436(\mathrm{~g})$, and therefore potentially increasing the risk of liability under the federal securities laws, could significantly improve investor protection").

138. See Danielle Carbone, The Impact of the Dodd-Frank Act's Credit Rating Agency Reform on Public Companies, 24 INSIGHTS: THE CORP. \& SEC. LAW AdVISOR 1, 1 (2010).

139. See id. at 2 . 
capital in offerings registered under the Securities Act. The repeal of Rule $436(\mathrm{~g})$ immediately became a game of credit ratings chicken. ${ }^{140}$

The SEC blinked first. On July 22, 2010, the SEC's the Division of Corporation Finance issued a "no-action" letter to Ford Motor Credit Company LLC and Ford Credit Auto Receivables Two LLC, permitting them to omit credit ratings disclosure from a prospectus. ${ }^{141}$ The relief was temporary (it was scheduled to expire on January 24,2011), but the SEC subsequently cemented the relief, making it clear that NRSROs would not be subject to liability under section $11 .{ }^{142}$

This regulatory response to Dodd-Frank's elimination of Rule 436(g) was extraordinary. ${ }^{143}$ Essentially, the SEC refused to implement Congress's intent, and said so explicitly. The SEC's action was not without a rationale: the SEC publicly expressed a concern that certain parts of the asset-backed securities markets would not properly function if the SEC implemented the Dodd-Frank mandate. ${ }^{144}$ It is unclear whether those markets in fact would not have properly functioned, or whether the markets might have been transformed in ways that would have been fairer and more efficient. Nevertheless, the SEC flouted the obvious intent of Congress. As of early 2017, Congress had not reacted. And perhaps surprisingly, no investors or other plaintiffs have sued to challenge the SEC.

It remains unclear what might happen if NRSROs were subject to section 11 liability. One possibility is that certain markets, such as assetbacked securities, would contract. Another possibility is that some rating agencies might be willing to consent to include their credit rating in a prospectus or registration statement. It is unclear whether the resulting competition would be a race to the top or bottom, though it would more closely resemble the reputational capital view of rating agencies. The fact that NRSROs are not willing to play such a role supports the view that they continue to act as regulatory license providers, instead of information intermediaries.

In any event, the Rule $436(\mathrm{~g})$ episode illustrates the stickiness problem associated with a privatized regulatory function. Congress

140. See id.

141. See id.

142. See id.

143. See id. (describing the SEC's quick actions to restart the markets, including the issuance of a no-action letter, discussions with major Wall Street law firms, and website postings to clarify its interpretation, all within days).

144. See Dodd-Frank Act $\S 939 \mathrm{G}$; Concept Release on Possible Rescission of Rule 436(g) under the Securities Act of 1933, Release Nos. 33-9071, 34-60798, 96 SEC Docket 2719 (Oct. 7, 2009). 
passed a law governing both regulators and private actors. Private actors refused to comply with the law. Regulators acceded to the private actors' demands. And then, Congress did nothing in response. Although the direction of government power typically flows from legislators to regulators and then in the direction of private actors, in this case the power moved in the opposite direction, with private actors dictating to regulators that both of them would ignore the express will of the legislature.

In practical terms, the result of the SEC's rule providing that ratings are not considered a part of a registration statement is that credit rating agencies need not be concerned about a "due diligence" defense. To satisfy the defense, an agency would have needed to show that "after reasonable investigation, [it had] reasonable ground to believe and did believe ... that the [credit ratings] therein were true and that there was no omission to state a material fact required to be stated therein or necessary to make the statements therein not misleading." 145 Effectively, the SEC has signaled to NRSROs that such reasonable grounds are not necessary. Accordingly, there is no need for rating agency due diligence. Because of the SEC's munificence, the credit rating agencies cannot be liable as experts under section 11, even though Dodd-Frank clearly provides that they should be. Given these changes, it is not surprising that the informational value of credit ratings would decline after Dodd-Frank.

\section{Regulation $F D$}

The Dodd-Frank provisions related to Regulation FD also illustrate the stickiness of regulators' reliance on credit rating agencies. Section 939B of Dodd-Frank required that the SEC revise Regulation FD to remove the exemption for entities whose primary business is credit ratings. ${ }^{146}$ Regulation FD provides that when an issuer privately discloses material nonpublic information to certain persons, the issuer must also publicly disclose that information. ${ }^{147}$ Regulation FD was promulgated in 2000 to address the problem of "selective disclosure," when issuers privately disclosed information in circumstances that

145. 15 U.S.C. $\S 77 \mathrm{k}(\mathrm{b})(3)(2012)$.

146. Dodd-Frank Act $\S 939 \mathrm{~B}$.

147. Regulation FD prohibits covered issuers from selectively disclosing to four categories of persons: (i) broker-dealers and their associated persons, (ii) investment advisers and institutional investment managers and their associated persons, (iii) investment companies and their associated persons, and (iv) holders of the issuer's securities, under circumstances in which it is reasonably foreseeable that the holder will trade on the information. 17 C.F.R. $\S 243.100$ (2016). 
created unfair advantages for certain persons, including advantages those persons might gain by trading securities or providing advice based on the information. ${ }^{148}$

During and before the financial crisis, Regulation FD had explicitly exempted credit rating agencies. ${ }^{149}$ As a result, issuers were free to disclose nonpublic information to credit rating agency employees, who could then use that information in their rating evaluations. The exemption arguably gave credit rating agencies a significant market advantage not available to other institutions and individuals who could only obtain public information.

In the aftermath of the collapse of Enron, it became apparent that although the credit rating agencies frequently received inside information, they often did not use that information or reflect it in their ratings. Critics argued that the credit rating agencies should not be entitled to an exemption from Regulation FD. ${ }^{150}$ Congress heard evidence about Regulation FD and the credit rating agencies, but decided in its 2006 legislation to leave the exemption intact. ${ }^{151}$

The legislative history of Dodd-Frank reflects arguments about removing the Regulation FD exemption for credit rating agencies. The SEC conducted a Roundtable on Issues Related to the Oversight of Credit Rating Agencies on April 15, 2009, and experts submitted evidence about the likely effects of removing the exemption. ${ }^{152}$ This Roundtable framed the later debates about the Regulation FD exemption.

148. Final Rule: Selective Disclosure and Insider Trading, Exchange Act Release No. 33-7881, 51719 (2000), https://www.sec.gov/rules/final/33-7881.htm [https://perma.cc/U7ZV-DACP].

149. See id.

150. See Frank Partnoy, Rethinking Regulation of Credit Rating Agencies: An INSTITUTIONAL INVESTOR 13 (2009) (submitted as an exhibit as part of the SEC Roundtable); Frank Partnoy, Statement to the SEC Roundtable on Issues Related to the Oversight of Credit Rating Agencies (Apr. 15, 2009), https://www.sec.gov/spotlight/cra-oversight-roundtable/cra-oversightroundtable-transcript.txt [https://perma.cc/EK4X-NE2Z].

151. The major credit rating agencies, particularly S\&P, actively lobbied Congress during the debate about this legislation. When I testified before the House of Representatives, numerous S\&P managers were seated behind me, including S\&P's prominent First Amendment attorney, Floyd Abrams, who was present, not to testify, but because members of Congress and their staffs knew his reputation. See Legislative Solutions for The Rating Agency Duopoly: Hearing Before the H. Subcomm. on Cap. Mkts., Ins. \& Gov't Sponsored Enters., H. Comm. on Fin. Servs., 109th Cong. (2005) (statement of Frank Partnoy).

152. See Partnoy, Rethinking Regulation of Credit Rating Agencies, supra note 150, at 13 (submitted as an exhibit as part of the SEC Roundtable); Partnoy, Statement to the SEC Roundtable on Issues Related to the Oversight of Credit Rating Agencies, supra note 150 (noting that "Congress already has begun debating the extent to which the rating agencies should be held accountable as gatekeepers, and courts have recognized the errors in previous cases. Rating agencies should not be exempt from securities fraud liability, and they should not enjoy any special privilege over other gatekeepers in Section 11 of the Securities Act of 1933, Regulation FD, or elsewhere"). 
By 2010, public and congressional sentiment about the credit rating agencies was obviously less favorable than it had been during previous years, and it became apparent that Dodd-Frank would include numerous accountability provisions. In a savvy pivot, the credit rating agencies did not fight the immediate efforts to remove the Regulation FD exemption; instead, they began playing a longer game. In retrospect, the credit rating agencies' long-term strategy is apparent from the Congressional testimony regarding Regulation FD during the Dodd-Frank hearings. Regulation FD was not covered extensively during the Dodd-Frank hearings, so it is worth setting forth the testimony related to Dodd-Frank section $939 \mathrm{~B}$ in its entirety. ${ }^{153}$

At one point during the hearings, Representative Jackie Speier of California questioned the CEOs of S\&P, Moody's, and Fitch (Deven Sharma, Raymond W. McDaniel, and Stephen W. Joynt, respectively). ${ }^{154}$ Representative Speier asked generally about how the credit rating agencies would function if they no longer had access to selective disclosure of inside information by issuers.

Ms. SPEIER. There is a regulation FD that the agencies contend that the exemption is needed in order to fully evaluate credit risk. Most notoriously, even though Enron made nonpublic credit rating agency presentations, information about the risk described in those presentations was not reflected in Enron's credit ratings. So my question is, if we are talking about accountability, if we are talking about greater disclosure, why should you be eligible for this exemption from regulation FD?

Mr. MCDANIEL. We operated for 90 years before regulation FD became effective. I think we were able to do a very fine job during that period, and I think we would be able to operate without regulation FD exemption now.

Ms. SPEIER. Thank you.

Mr. Sharma?

Mr. SHARMA. Ratings are forward looking, and information that allows us-that gives us more insight as to the future helps us to make better decisions.

Ms. SPEIER. Mr. Joynt?

153. There is only one reference to Regulation FD in the legislative history of Dodd-Frank. See Rick McKinney, Dodd-Frank Wall Street Reform and Consumer Financial Protection Act: A Brief Legislative History, LLSDC (July 29, 2015), http://www.llsdc.org/dodd-frank-legislative-history [https://perma.cc/23YY-2ENK].

154. Reforming Credit Rating Agencies: Hearing Before the Subcomm. on Cap. Mkts., Ins., and Gov't Sponsored Enters., H. Comm. on Fin. Servs., 111 th Cong. 38 (2009). 
Mr. JOYNT. I would agree. I think that regulation was passed to allow issuers to more freely communicate with rating agencies so they can make better decisions.

Ms. SPEIER. But we have lots of examples where it wasn't used in that way. So the question is, is it going to hurt your business if we get rid of that exemption?

Mr. JOYNT. I believe we could continue to offer educated opinions. ${ }^{155}$

The CEOs' responses suggest there would not be negative consequences to Congress removing the Regulation FD exemption. The implication of their answers was that the rating agencies could function well without access to inside information from issuers. However, consider what happened next, after Dodd-Frank passed.

The credit rating agencies immediately lobbied the SEC to make it clear in its release implementing section 939B that issuers submitting material nonpublic information to NRSROs solely for the purpose of obtaining credit ratings would not violate Regulation FD. ${ }^{156}$ Specifically, the particular regulation at issue, Rule 100 (b)(2)(iii), provided that the Regulation FD requirement to disclose information publicly would not be triggered if a selective disclosure was made to an NRSRO. ${ }^{157}$ The credit rating agencies wanted the SEC to make it clear that issuers did not need to worry about the removal of this provision because there still would be other bases for issuers to selectively disclose inside information to NRSROs. In other words, the credit rating agencies were asking for the SEC to declare section 939B of Dodd-Frank a nullity.

The SEC gave the credit rating agencies what they had lobbied for. In its release implementing section 939B, the SEC deleted Rule 100(b)(2)(iii), the provision exempting NRSROs. However, the SEC also set forth a roadmap for the credit rating agencies to continue to receive selective disclosures of material non-public information, in a footnote of the implementing release. ${ }^{158}$ Essentially, the suggestion was

155. Id.

156. See Letter from Vickie A. Tillman, Exec. Vice President, Standard and Poor's Inv. Ratings Servs., to Elizabeth M. Murphy, Sec'y, Sec. \& Exch. Comm'n (Mar. 26, 2009), http://www.sec.gov/comments/s7-04-09/s70409-18.pdf [https://perma.cc/LNE4-TX3D]; Letter from Michel Madelain, Chief Operating Officer, Moody's Investors Serv., to Elizabeth M. Murphy, Sec'y, Sec. \& Exch. Comm'n (Mar. 28, 2009), http://www.sec.gov/comments/s7-04-09/s7040920.pdf [https://perma.cc/S2ED-CASE].

157. 17 C.F.R. 243.100(b)(2)(iii) (2016).

158. Footnote 9 stated:

Regulation FD also provides exemptions for communications made to a person who owes the issuer a duty of trust or confidence-i.e., a "temporary insider"-such as an attomey, 
that NRSROs could claim exemption as temporary insiders, like attorneys, investment bankers, and accountants, who remained exempt from Regulation FD. Note that the SEC accepted the opposite argument with respect to section 11 liability: there, attorneys, investment bankers, and accountants are subject to liability, but NRSROs are not.

Subsequently, the leading credit rating agencies assured issuers that, notwithstanding the regulatory changes, issuers could continue to disclose inside information to NRSROs. ${ }^{159}$ Law firms advising issuers opined that the changes in Regulation FD would have little or no impact on selective disclosures made to credit rating agencies. ${ }^{160}$ One prominent law firm suggested that the SEC's actions-and the rating agencies' positions-were potentially contrary to Congressional intent, warning:

Much ado about nothing? Perhaps. However, the directive to the SEC to remove the rating agency exemption may well evidence an intent by the legislators to require the public disclosure of material nonpublic information provided to the rating agencies in certain circumstances. It is uncertain whether Congress will be satisfied by the mere repeal of Rule 100(b)(2)(iii) and the continuation of business as usual. ${ }^{161}$

In any event, business continued as usual. The changes to Regulation FD had no impact on NRSROs, for at least three reasons. First, the NRSROs maintained that the new rules did not cover them. Specifically, they argued that NRSROs did not fall within any of the specified categories of persons to whom selective disclosure was prohibited. ${ }^{162}$

investment banker, or accountant..., to any person who expressly agrees to maintain the information in confidence..., and in connection with most offerings of securities registered under the Securities Act ... . These exemptions are unaffected by the Act.

Removal from Regulation FD of the Exemption for Credit Rating Agencies, Exchange Act Release No. 33-9146, 34-63003, 99 SEC Docket 1503, n.9 (Sept. 29, 2010).

159. According to one law firm advising issuers:

The NRSROs that have publicly addressed the issue do not believe that the removal of the exemption will affect the way in which issuers share material nonpublic information with the rating agencies as part of the ratings process. In this regard, they do not believe that they fall within any of the enumerated categories of persons to whom selective disclosure is prohibited and their policies prohibit trading on material nonpublic information. In addition, the engagement letter that the rating agency enters into with the issuer contains confidentiality provisions which should allay concerns that companies may nonetheless have about the effect of the removal of the exemption.

Carbone, supra note 138 , at 5 .

160. See id. (relying on exemption for disclosures made in confidence).

161. Janette A. McMahan \& Kelly A. Schell, Much Ado About Nothing?, KIRKLAND ALERT 2 (Oct. 2010).

162. Id. 
Second, the NRSROs contracted around the Dodd-Frank Regulation FD provisions: they changed their internal policies regarding trading based on material nonpublic information and the handling of confidential information to match the language in the extant Regulation FD exceptions. ${ }^{163}$ In other words, the rating agencies could not change the language of Dodd-Frank, so they changed their own practices to remove themselves from application of that language.

Third, given the dearth of SEC's actions based on Regulation FD, an economically rational NRSRO and the relevant issuer had little to fear from the selective disclosure of information by issuers, notwithstanding the limitations in Dodd-Frank. My research has not uncovered any challenges by the SEC to NRSRO practices regarding Regulation FD. ${ }^{164}$

The machinations surrounding Regulation FD are another troubling example of the stickiness of regulatory reliance of private actors. The initial market failure, the informational asymmetry between issuers and investors, was exacerbated by the regulatory failure (exempting credit rating agencies from disclosure provisions), which was exacerbated by further market failure (lobbying by the focused interests of the NRSROs), which was worsened by further regulatory failure (the SEC ignoring the will of Congress, and then Congress not responding).

\section{B. Litigation}

Dodd-Frank also included reforms related to potential securities litigation against credit rating agencies. Those reforms included a statement that the enforcement, mental state, and forward-looking statement provisions of the securities law apply to credit rating agencies in the same manner and to the same extent as they apply to registered public accounting firms or securities analysts. ${ }^{165}$ This Article next considers accountability through litigation.

In general, the courts have played only a limited role in the aftermath of the financial crisis. ${ }^{166}$ Only a handful of private cases were brought against credit rating agencies in response to losses sustained by investors

163. See, e.g., Press Release, Fitch Ratings, Fitch Comments on U.S. Financial Reform Act's Implication for Credit Rating Agencies (July 19, 2010), http://www.businesswire.com/news/home 120100719006158/en/Fitch-Comments-U.S.-Financial-Reform-Acts-Implication [https://perma.cc/V 7WE-7VGD] ("To the greatest extent possible, Fitch will work with the issuer community to put in place appropriate mechanisms so that Fitch can continue to receive confidential information as part of the rating process.").

164. The OCR's annual reporting does not mention any such actions.

165. See Dodd-Frank $\S 933$.

166. See generally David Zaring, Litigating the Financial Crisis, 100 VA. L. REV. 1405 (2014). 
during the financial crisis. Moreover, post-Dodd-Frank, there have been no major cases filed against the major rating agencies. ${ }^{167}$

Moody's has included disclosure about litigation arising out of the financial crisis in its annual securities filings, including some detail about these cases. ${ }^{168}$ Each resulted in significant settlements. ${ }^{169}$ However, each also illustrates why credit rating agencies are unlikely to be held accountable through litigation in the future. ${ }^{170}$

Abu Dhabi Commercial Bank v. Morgan Stanley \& Co. ${ }^{171}$ involved allegations related to a 2005 "structured investment vehicle" (SIV) called Cheyne Finance. ${ }^{172}$ Documents in the case showed that the individuals involved in structuring and selling the Cheyne transactions did not follow any rational or established methodology to arrive at the high ratings. For example, S\&P's lead analyst wrote in an e-mail to a colleague that "I had difficulties explaining 'HOW' we got to those numbers since there is no science behind it"; likewise, the lead analyst at Moody's stated that there was "no actual data backing the current model assumptions" for Cheyne. ${ }^{173}$ In one instance, a Morgan Stanley executive effectively pressured $S \& P$ to raise its rating on a portion of the Cheyne debt from BBB to single-A. ${ }^{174}$

The rating agencies had argued in past cases that their ratings were merely opinions and were protected as free speech. ${ }^{175}$ Scholars have criticized this argument, but the rating agencies have pressed it and won-both in the courts and in the media. ${ }^{176}$ Judge Scheindlin in $A b u$

167. As of early 2017, neither Moody's nor S\&P had publicly disclosed more recent litigation in their securities filings.

168. See Moody's 2016 Form 10-K, supra note 27, at 27, 44, 105-06.

169. Id

170. There also have been a few cases outside the U.S. involving credit rating agencies. For example, Australian courts have found S\&P liable for issuing misleading AAA ratings of complex structured products. See ABN AMRO Bank NV v Bathurst Regional Council [2014] FCR 65 (Austl.).

171. 888 F. Supp. 2d 431 (S.D.N.Y. 2012). I acted as a consulting attorney for plaintiffs in this case.

172. Id. at $440-41$.

173. Jeannett Neumann, Cost of Ratings Suit: \$225 Million, WaLL ST. J. (Apr. 29, 2013) https:/www.wsj.com/articles/SB10001424127887323528404578453292918428224

[https://perma.cc/B47X-BDSB]; see also Gretchen Morgenson, Court Papers Undercut Ratings Agency Defense, N.Y. TIMES, July 3, 2012, at B1.

174. See Morgenson, supra note 173.

175. Some U.S. courts previously had found that credit ratings were protected speech. See, e.g., Jefferson Cty. Sch. Dist. v. Moody's Inv'r's Servs., Inc., 175 F.3d 848, 852-56 (10th Cir. 1999); In re Enron Corp. Sec., Derivative \& "ERISA" Litig., 511 F. Supp. 2d 742, 819-27 (S.D. Tex. 2005).

176. See Caleb Deats, Note, Talk that Isn't Cheap: Does the First Amendment Protect Credit Rating Agencies' Faulty Methodologies from Regulation?, 110 COLUM. L. REV. 1818 (2010); Nan $\mathrm{S}$. Ellis et al., Is Imposing Liability on Credit Rating Agencies a Good Idea?: Credit Rating Agency 
Dhabi held that the ratings were properly alleged to have been actionable misrepresentations, not opinions, ${ }^{177}$ but suggested that the First Amendment might have protected the rating agencies if the ratings had been widely disseminated and therefore were considered matters of public concern. ${ }^{178}$ The case ultimately settled for a reported $\$ 225$ million. ${ }^{179}$

A second SIV-related case, California Public Employees Retirement System v. Moody's Corp., ${ }^{180}$ was filed in state court in California by CalPERS in 2009. That litigation involved similar claims and First Amendment arguments to $A b u D h a b i$, and also was protracted and costly; ${ }^{181}$ S\&P settled the case for $\$ 125$ million in early 2015 , and Moody's for $\$ 130$ million in March 2016, on the eve of trial. ${ }^{182}$

The most significant financial crisis case involving rating agencies was the $\$ 1.375$ billion settlement of a 2013 civil complaint brought by the Department of Justice (DOJ) and nineteen states against S\&P. ${ }^{183}$

Reform in the Aftermath of the Global Financial Crisis, 17 STAN. J.L. BUS. \& FIN. 175, 221-22 (2012); Partnoy, supra note 13, at 61. Other scholars have argued that imposing liability on credit rating agencies could be counterproductive, in part because liability could lead credit rating agencies to give ratings that were suboptimally low. See Dimitrov et al., supra note 30, at 513-14; Anand M. Goel \& Anjan V. Thakor, Credit Ratings and Litigation Risk, at 1 (Mar. 15, 2011) (unpublished manuscript), https://ssm.com/abstract=1787206 [https://perma.cc/HAU7-TPXS].

177. See Abu Dhabi Commercial Bank v. Morgan Stanley \& Co., 888 F. Supp. 2d 431, 454 (S.D.N.Y 2012).

178. See id. at 175.

179. See Susan Beck, Susan Beck's Summary Judgment: Blowback for the Rating Agencies, THE LiTIG. DAILY (May 8, 2013), https://advance.lexis.com/search?crid=eed6d6c9-d2 le-4e5c-866e-d $10 f 362$ b6277\&pdsearchterms=LNSDUID-ALM-AMLAWR-1202599298421\&pdbypasscitatordocs $=$ False \&pdmfid=1000516\&pdisurlapi=true [https:/perma.cc/8KU6-DT7G] (describing \$225 million settlement); Alison Frankel, Will CDO Investors' Deal Boost Litigation Against Rating Agencies?, REUTERS (Apr. 29, 2013), http://www.reuters.com/article/idUS170095852220130429 [https://perma.cc/5G2Q-CSFE]; Matt Taibbi, The Last Mystery of the Financial Crisis, RoLLING STONE (June 19, 2013), http:/www.rollingstone.com/politics/news/the-last-mystery-of-thefinancial-crisis-20130619 [https://perma.cc/DVA9-FGAR] (describing \$225 million settlement).

180. No. CGC-09-490241, 2010 WL 2286924 (Cal. Super. Ct. May 24, 2010).

181. See Moody's 2016 Form 10-K, supra note 27, at 106.

182. See Joel Rosenblatt \& Matt Scully, Moody's Settles Calpers Ratings Lawsuit for $\$ 130$ Million, BLOOMBERGTECHNOLOGY (Mar. 9, 2016) https://www.bloomberg.com/amp/news/articles /2016-03-09/calpers-says-moody-s-to-pay-130-million-to-settle-ratings-case [https://perma.cc/WX D4-LZVD]. The only other lawsuit Moody's deemed sufficiently material to disclose was a 2008 claim by Pursuit Partners arising out of the sale by UBS of five CDOs; that case was litigated for seven years until it settled, confidentially, during jury selection before trial. Alleged damages had been $\$ 44$ million. See Moody's 2016 Form 10-K, supra note 27, at 106-07.

183. See Press Release, Statement of Attorney General Eric Holder, Justice Department and State Partners Secure $\$ 1.375$ Billion Settlement with S\&P for Defrauding Investors in the Lead Up to the Financial Crisis, U.S. Dep't of Justice (Feb. 3, 2015), https://www.justice.gov/opa/pr/justicedepartment-and-state-partners-secure-1375-billion-settlement-sp-defrauding-investors 
That case alleged violations of the Financial Institutions Reform, Recovery, and Enforcement Act of 1989 (FIRREA), a novel theory. ${ }^{184}$ The DOJ alleged that S\&P had made numerous fraudulent misrepresentations, including representations regarding the independence of S\&P ratings of several RMBS and CDOs. ${ }^{185} \mathrm{~S} \& \mathrm{P}$ did not admit wrongdoing, though it was required to retract its earlier assertion that the lawsuit was political retaliation for the firm's 2011 downgrade of the United States's credit rating. ${ }^{186}$

On January 13, 2017, during the final week of the Obama administration, Moody settled similar FIRREA charges related to structured finance ratings with the DOJ and states' attorneys general for $\$ 864$ million. ${ }^{187}$ The agreement lacked the public findings of the case against S\&P (or even a complaint). ${ }^{188}$ In announcing the settlement, Moody's emphasized that it "stands behind the integrity of its ratings, methodologies and processes, and the settlement contains no finding of any violation of law, nor any admission of liability." 189

Overall, the litigation against the credit rating agencies sends a mixed message regarding accountability. On one hand, the credit rating agencies paid substantial sums to settle a handful of cases. On the other hand, those cases were challenging and expensive to prosecute, and to some extent were successful due to their uniqueness.

Importantly, the credit rating agencies' First Amendment arguments remain an obstacle to future litigation. Given recent cases, the extent to which courts will regard credit ratings as merely commercial activity as opposed to statements of opinion about matters of public importance remains unclear. In section 931 of Dodd-Frank, Congress expressed some skepticism about the credit rating agencies' free speech assertions and defenses. Section 931(2) states that credit rating agencies play a "gatekeeper" role in the debt market that "is functionally similar to that of securities analysts." 190 Implicit in that statement is an understanding that the "opinions" of securities analysts are subject to extensive regulation and are not considered protected speech, and credit rating agencies' "opinions" are similar and should be treated similarly.

[https://perma.cc/9TCK-MQGD].

184. See 12 U.S.C. \& 1833a (2012).

185. Id.

186. See Press Release, Statement of Attorney General Eric Holder, supra note 183.

187. Id.

188. Moody's Corp., Current Report (Form 8-K), at exhibit 99.1 (Jan. 13, 2017).

189. See id.

190. Dodd-Frank Act $\S 929-Z$. 
Congress also found that "the activities of credit rating agencies are fundamentally commercial in character and should be subject to the same standards of liability and oversight as apply to auditors, securities analysts, and investment bankers." ${ }^{191}$ However, based on the rulings in the above cases, the possibility of a free speech defense appears to remain, depending on the facts.

Considering both the legislative reforms in Dodd-Frank and the judicial approaches to the small number of cases against credit rating agencies, there is only limited accountability for credit rating agencies. Given the limitations associated with both oversight and accountability, the next question is how the rating agency methodologies compare to those that were central to the financial crisis.

\section{METHODOLOGIES}

This section will focus on several methodological areas that are arguably the most important from a policy perspective and that in any event have received considerable attention from the credit rating agencies themselves. This section will address approaches at both S\&P and Moody's. The serious methodological flaws described in this section are strong evidence of why credit ratings continue to have little informational value. The flaws documented here also illustrate why the stickiness of reliance on credit rating agencies is problematic, and why institutions should not continue to rely substantially on credit ratings. The credit rating agencies' methodologies have not responded in any meaningful way to the major problems that contributed to the financial crisis.

One of the central methodological problems with credit ratings has been credit rating agencies' assessment of arbitrary distinctions, often with subjective adjustments to account for errors that arise from the arbitrary process. Scholars have recognized the pervasive nature of such methodological problems with respect to the mortgage-related debt instruments at the core of the recent financial crisis. ${ }^{192}$ Unfortunately, those methodological problems continue, even after the various reforms, and they are not limited to mortgage-related debt instruments.

Instead of recognizing that credit risks, and the underlying factors that drive credit risks, involve the complex interactions of various financial and human variables, credit rating agency methodologies continue to rely on the simplistic categorization and addition of numerical

191. Id.

192. See Griffin \& Tang, supra note 111 , at 1294. 
assessments in different, overlapping categories. The methodologies do not resemble those used by sophisticated market participants and intermediaries who assess credit risk. Instead, the rankings within categories-and often the categories themselves-are overly-simplistic and arbitrary. The section begins the analysis with S\&P's corporate rating methodology.

\section{A. An Overview of Corporate Rating Methodology}

In the aftermath of the financial crisis, S\&P revised its methodological approach to corporate ratings. The literature has not assessed this new methodology in any detail. This section considers S\&P's revised approach.

S\&P's revised methodological approach involves the serial assessment of several factors: (1) business risk, (2) financial risk, (3) anchor, and (4) modification. ${ }^{193}$ First, S\&P determines a company's business risk profile by analyzing its country risk, industry risk, and competitive position. ${ }^{194}$ Second, S\&P determines a company's financial risk profile by analyzing its cash flow and leverage. ${ }^{195}$ Third, S\&P determines its ratings "anchor" by combining the business and financial risk profiles. Finally, S\&P looks at six other factors that can lead to adjustments to the anchor. ${ }^{196}$ The four-step methodology has the appearance of some analytical precision, at least in separating various questions relevant to determinations of credit risk. However, a closer look at each step reveals the arbitrary nature of S\&P's revised methodology.

\section{Business Risk}

Business risk is composed of three sub-factors. ${ }^{197}$ The methodology for translating each of the three business risk sub-factor six-point ratings into the overall business risk six-point rating resembles a Russian nesting doll. First, S\&P calculates two of the underlying business risk factors - country risk and industry risk - and then combines them based on the following grid to obtained a "Corporate Industry and Country

193. See Standard \& Poor's Ratings Serv., Corporate Methodology 3 (2013) [hereinafter S\&P'S, CORPORATE METHODOLOGY].

194. Id. at 3-4.

195. Id. at 5.

196. Id.

197. Id. at 6-8. 
Risk Assessment" (CICRA). ${ }^{198}$ The grid is set forth below (the columns are the Country Risk Assessment; the rows are the Industry Risk Assessment):

\begin{tabular}{|c|c|c|c|c|c|c|c|}
\hline \multicolumn{9}{|c|}{ Country } \\
\hline \multirow{4}{*}{ Industry } & & 1 & 2 & 3 & 4 & 5 & 6 \\
\cline { 2 - 8 } & 1 & 1 & 1 & 1 & 2 & 4 & 5 \\
\cline { 2 - 8 } & 2 & 2 & 2 & 2 & 3 & 4 & 5 \\
\cline { 2 - 8 } & 3 & 3 & 3 & 3 & 3 & 4 & 6 \\
\cline { 2 - 8 } & 4 & 4 & 4 & 4 & 4 & 5 & 6 \\
\cline { 2 - 8 } & 5 & 5 & 5 & 5 & 5 & 5 & 6 \\
\cline { 2 - 8 } & 6 & 6 & 6 & 6 & 6 & 6 & 6 \\
\hline
\end{tabular}

Table 1:

\section{Determination of "CICRA"}

Note the bizarre normative judgments S\&P has made in this grid. The country risk assessment is irrelevant to the CICRA so long as the country is in the first three categories of risk (meaning that the industry risk numbers remain constant regardless of the country risk rating). But once the country risk assessment falls to 5 or 6 , the CICRA plummets. ${ }^{199}$ S\&P does not point to any data or research that supports such a sharp and discontinuous decline. One typically would expect an explanation for such a decline to be presented within the published methodology, but it is not. It is unclear the extent to which these mappings are based on historical assessments that might not hold into the future. The bases for the mappings are not transparent.

Moreover, S\&P's underlying country risk assessment sub-categories are based on factors that would not support the grid's implicit adjustments. Indeed, S\&P asserts that it engaged in extensive review and testing in order to determine that each of the four sub-factors that are relevant to determining the Country Risk Assessment should be equally weighted. ${ }^{200}$ An equal weighting of sub-factors - each of which is, in turn, rating on a six-point scale-would be inconsistent with the discontinuous mappings in the above grid. S\&P also includes numerous caveats and exceptions in its sub-factor assessments; to the extent the

198. Id. at 6 .

199. S\&P's, CoRporate METHOdOLOGY, supra note 193, at 7 tbl.1.

200. See Standard \& Poor's Ratings Serv., Country Risk Assessment Methodology AND ASSUMPTIONS 7 (2013). 
sub-factors were assessed correctly, the discontinuities in the above grid should not have been necessary. ${ }^{201}$

Next, S\&P determines a company's "competitive risk assessment." This determination requires a trip down yet another credit-related rabbit hole. A company's "competitive risk assessment" includes numerous subjective judgments about four sub-factors: the company's competitive advantage; scale, scope, and diversity; operating efficiency; and profitability. ${ }^{202}$ The competitive risk assessment is made on yet another arbitrary six-point scale - excellent, strong, satisfactory, fair, weak, and vulnerable-with each of the first three sub-factors receiving a weighting and a ranking on a separate five-point scale. ${ }^{203}$

Each company is put into one of six groups called "Competitive Position Group Profiles" (CPGP): "services and product focus;" "product focus/scale driven;" "capital or asset focus;" "commodity focus/cost driven;" "commodity focus/scale driven;" or "national industries and utilities." 204 The category matters a great deal. The "competitive advantage" sub-factor has only a $10 \%$ weighting in the "commodity focus/cost driven" group, but a $60 \%$ weighting in the "national industries and utilities" group. The "operating efficiency" subfactor has a $15 \%$ weighting in the "product focus/scale driven" group, but a $40 \%$ weighting in the "capital or asset focus" group.

S\&P admits that the judgments made as part of this assessment are "qualitative." 205 But a close examination of the details reveals just how nonsensical its qualitative assessment is. S\&P provides a four-page appendix to its methodology including the mappings between various industry categories and subsectors and their corresponding CPGP ${ }^{206}$ The categorizations are baffling. A company in "paper packaging" is grouped with airlines, technology distributors, semiconductors, film and TV

201. See id. ("After extensive review and testing, we have concluded that an equal weighting of the four sub-factors is the most representative approach to country risk. While the risk profiles in some countries might temporarily suggest a different weighting (such as when domestic hostilities break out or a banking crisis is under way), we did not find any one risk more determinant than others over time for the majority of countries. Still, to recognize the importance and potential for periodic sharp hikes in one type of risk, we introduced judgmental weighting on a case-by-case basis (per paragraph 49 , we may round a country risk assessment weaker in case of 'One type of risk being or becoming dominant that would cause us to add additional weight to an unfavorable sub-factor and reduce weight to a more favorable sub-factor(s)."'),

202. See S\&P's, CORPORATE METHODOLOGY, supra note 193 , at 15.

203. Id. at 16 .

204. Id. at 23.

205. Id. at 15.

206. See id. at 54-57. 
programming production, fiber-optic carriers, and offshore contract drilling (all "capital or asset focus"), whereas a company in "paper products" is grouped with coal and consumable fuels, aluminum, and diversified chemicals (all "commodity focus/cost driven"). ${ }^{207}$ The category of casinos and gambling is grouped with aerospace and defense, construction and engineering, cable TV networks, home furnishing retail, and IT consulting ("service and product focus"). ${ }^{208}$

The specific considerations for each sub-factor are at least as arbitrary as the group weighting determinations, and include their own detailed appendices, tables, and subjective factors. In making determinations related to the "competitive advantage" sub-factor, S\&P considers the following: "Strategy; Differentiation/uniqueness, product positioning/bundling; Brand reputation and marketing; Product/service quality; Barriers to entry, switching costs; Technological advantage and capabilities, technological displacement; and Asset profile." 209 For the "scale, scope, and diversity" sub-factor, S\&P considers, "Diversity of product or service range; Geographic diversity; Volumes, size of markets and revenues, and market shares; and Maturity of products or services." 210 For the "operating efficiency" sub-factor, S\&P considers, "Cost structure, Manufacturing processes, Working capital management, and Technology."211

Once these sub-factor calculations are made, S\&P combines the preliminary competitive position assessment with its profitability assessment to get a result that is biased in favor of the preliminary competitive position assessment. ${ }^{212}$ There is yet another grid setting forth this supposed balancing. ${ }^{213}$ 


\begin{tabular}{|c|c|c|c|c|c|c|c|}
\hline \multicolumn{9}{|c|}{ Preliminary Competitive Position Assessment } \\
\hline \multirow{4}{*}{\begin{tabular}{c} 
Profitability \\
\cline { 2 - 8 } Assessment
\end{tabular}} & & 1 & 2 & 3 & 4 & 5 & 6 \\
\cline { 2 - 8 } & 2 & 1 & 2 & 2 & 3 & 4 & 5 \\
\cline { 2 - 8 } & 3 & 2 & 2 & 3 & 3 & 4 & 5 \\
\cline { 2 - 8 } & 4 & 2 & 3 & 3 & 4 & 4 & 5 \\
\cline { 2 - 8 } & 5 & 2 & 3 & 4 & 4 & 5 & 6 \\
\cline { 2 - 8 } & 6 & 2 & 3 & 4 & 5 & 5 & 6 \\
\hline
\end{tabular}

Table 2:

Determination of "Competitive Position" Assessment

Note that this grid replicates many of the bizarre discontinuous characteristics of the previous grids. Then, once $S \& P$ has calculated the CICRA and competitive position assessment for a particular company, it matches them against each other in order to determine the company's business risk profile, based on the following grid ${ }^{214}$ :

\begin{tabular}{|c|c|c|c|c|c|c|c|}
\hline \multicolumn{1}{|c|}{} & & 1 & 2 & 3 & 4 & 5 & 6 \\
\cline { 2 - 9 } & 1 & 1 & 1 & 1 & 2 & $3^{*}$ & 5 \\
\cline { 2 - 8 } Competitive \\
\cline { 2 - 8 } Position & 2 & 1 & 2 & 2 & 3 & 4 & 5 \\
\cline { 2 - 8 } Assessment & 3 & 2 & 3 & 3 & 3 & 4 & 6 \\
\cline { 2 - 8 } & 4 & 3 & 4 & 4 & 4 & 5 & 6 \\
\cline { 2 - 8 } & 5 & 4 & 5 & 5 & 5 & 5 & 6 \\
\cline { 2 - 9 } & 6 & 5 & 6 & 6 & 6 & 6 & 6 \\
\hline
\end{tabular}

Table 3:

\section{Determination of "Business Risk" Profile}

Note that this grid also replicates most of the characteristics of the previous mappings in the country-industry grid, but with a few even stranger changes. First, the business risk profile is slightly higher for companies with a CICRA of 1 . Second, companies with a CICRA of 5 are potentially given a business risk profile of 2 , depending on a range of subjective factors. ${ }^{215} \mathrm{~S} \& \mathrm{P}$ also includes several "weighted" factors,

\section{See id. at 7.}

215. For example, $S \& P$ notes that a business risk profile of 2 may be assigned to a company with a CICRA of 5 if, among other things, "[t] $]$ he company's competitive position within its sector transcends its industry risks due to unique competitive advantages with its customers, strong 
depending on the company's different business lines and industries, but only if they exceed a specified fixed percentage (e.g., $5 \%$ of the company's sales). ${ }^{216}$ Once again, there is no transparency regarding these mappings, and S\&P does not cite to any literature that might support them.

More important, the methodology is not replicable. There are enough numbers and charts to lend the appearance of objectivity, and yet the underlying determinants of the rating remain hidden. The business risk assessment methodology is a black box, within a black box, within a black box.

\section{Financial Risk Assessment}

After the business risk assessment, the revised S\&P methodology turns to the second key determinant of an anchor rating: the financial risk assessment. The analysis of financial risk assessment is focused on a company's pattern of cash flow generation relative to its cash obligations. In S\&P's judgment, such analysis "is often the best indicator of a company's financial risk." 217

Indeed, there are well-established methodologies that assess financial risk, such as Altman Z-Scores. Altman Z-Scores are based on transparent and replicable measures derived from financial statement information about cash flow generation relative to cash obligations, including variables such as working capital, retained earnings, earnings before interest and tax, and sales, as compared to total assets; and the market value of equity relative to total liabilities. ${ }^{218}$ Alternatively, consulting firms such as Kamakura, as well as smaller credit rating agencies such as Kroll, provide credit risk assessment that is more detailed and analytical, albeit not transparent or replicable to the same degree as Altman Z-scores. ${ }^{219}$

In contrast, S\&P's financial risk assessment is facile, even compared to what is taught in basic law and finance courses. ${ }^{220}$ Its calculation of a

operating efficiencies not enjoyed by the large majority of the industry, or scale/scope/diversity advantages that are well beyond the large majority of the industry." Id. at 7 .

216. Id. at 8 .

217. Id. at 29 .

218. See Edward I. Altman, Financial Ratios, Discriminant Analysis and the Prediction of Corporate Bankruptcy, 23 J. FiN. 589 (1968). Altman Z-Scores, and related methodologies, continue to be widely used today.

219. See Kamakura, supra note 10.

220. See, e.g., Alan R. Palmiter \& Frank Partnoy, Corporations: A Contemporary APPROACH, chs. 9-10 (2d ed. 2014) (describing various analytic approaches to financial statement 
company's financial risk assessment follows several steps. According to S\&P:

We derive the final cash flow/leverage assessment for a company by determining the relevant core ratios, anchoring a preliminary cash flow assessment based on the relevant core ratios, determining the relevant supplemental ratio(s), adjusting the preliminary cash flow assessment according to the relevant supplemental ratio(s), and, finally, modifying the adjusted cash flow/leverage assessment for any material volatility. ${ }^{221}$

Unlike well-established financial risk assessment methodologies, the calculations at each step are hidden; one cannot precisely replicate how S\&P is making determinations at each stage.

S\&P also provides that a firm's "financial policy" or "financial discipline" can change its financial risk profile. ${ }^{222}$ Such changes are based on a subjective assessment by S\&P employees. ${ }^{223}$ S\&P anticipates that corporate managers will find it difficult to assess how S\&P might assess these subjective factors, so the methodology includes five case examples, presumably to give some guidance. ${ }^{224}$ However, those case examples raise more questions than they answer. Consider the following example:

Example 5: A company (not owned by a financial sponsor) has very solid financial ratios, providing it with meaningful flexibility for M\&A when compared with management's longterm stated financial policy. Also, its stock price performance is somewhat below that of its closest industry peers. Although we have no recent evidence of any aggressive financial policy steps, we fundamentally believe that, over the long-term term, the company will end up using its financial flexibility for the right M\&A opportunity, or alternatively return cash to shareholders. ${ }^{225}$

What kind of an impact might the managers of such a company expect would arise from the subjective considerations made by S\&P employees? All the objective indicia are positive, including solid financial ratios. Moreover, the example explicitly assumes that "we have

and valuation analysis).

221. S\&P's, CORPORATE METHODOLOGY, supra note 193, at 30.

222. See id. at $43-49$.

223. Id.

224. Id. at 73-74.

225. See id. at 74 . 
no recent evidence of any aggressive financial policy steps."226 Any reasonable reading of the example would suggest that the subjective interpretation should be positive.

Yet S\&P's answer to Example 5 is jarring: a one-notch downgrade:

Likely outcome: Negative financial policy impact. Long-term event risk derived from M\&A cannot be built into forecasts nor shareholder returns (share buybacks or one-off dividends) be built into forecasts to attempt aligning projected ratios with stated long-term financial policy levels. This is because our forecasts are based on realistic and reasonably predictable assumptions for the medium term. The anchor will be adjusted down, by one notch or more, because of the negative financial policy assessment. ${ }^{227}$

In this case, S\&P's methodology leads to a subjective negative adjustment, the opposite of the one many scholars cited as arising during the years before the recent financial crisis. ${ }^{228}$ That distinction is important. My argument here is not that S\&P's methodology necessarily leads to unrealistically optimistic ratings. Nor is it specifically that S\&P's methodology leads to ratings that are unjustifiably high. Indeed, the opposite might very well be the case. Instead, my claim is that the methodology is unpredictable and indecipherable. It is not replicable. Neither an issuer nor an investor can read S\&P's revised methodology closely and anticipate what their credit rating will be at any given moment, or how any actions will impact future ratings. This opacity is particularly important for investors. It means that the credit rating's utility does not derive from a transparent understanding of the process.

\section{Anchor Rating}

Once an S\&P analyst has assessed business and financial risk, the next step in S\&P's revised methodology combines the business and financial risk profiles to arrive at an "anchor" rating, as follows ${ }^{229}$ :

226. $I d$.

227. See id.

228. See Griffin \& Tang, supra note 111 , at 1307.

229. S\&P's, CORPORATE METHODOLOGY, supra note 193, at B. 


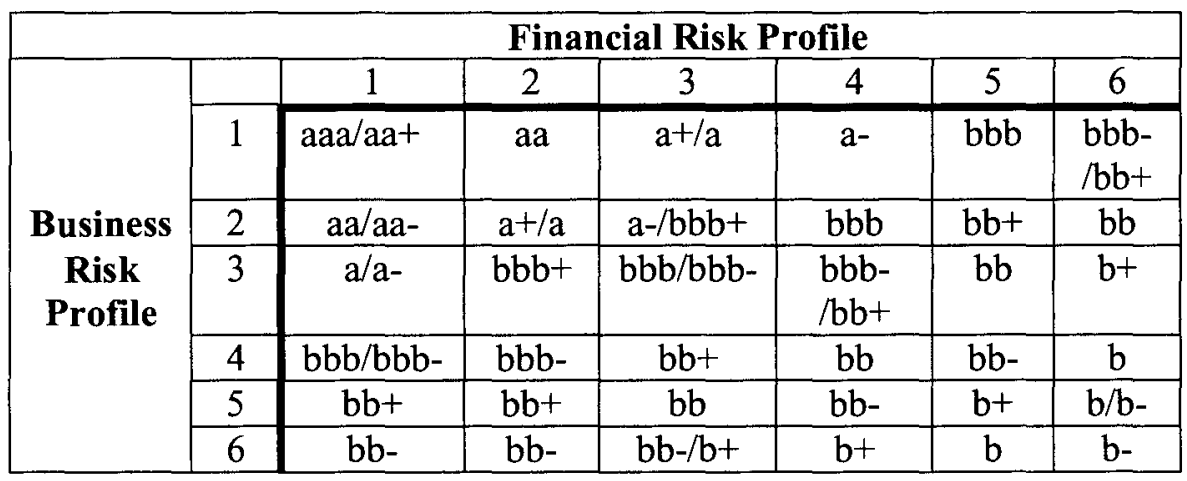

\section{Table 4: \\ Determination of "Anchor Rating"}

The differences among the cells in the grid raise numerous additional methodological questions. ${ }^{230}$ What is the rationale for having two possible ratings in some circumstances but not others? Why aren't the changes in anchor ratings consistent for different changes in financial risk and business risk profiles? For example, why does the anchor rating fall at least one rank for declines in the financial risk rating below 2 but remain the same between 1 and 2? Why doesn't the anchor rating change by a consistent number of notches for given changes in the financial and business risk profiles? For example, for numerous cells in the chart, the decline in anchor rating for a one point decline in either business or financial risk profile is one notch (e.g., a company with a financial risk profile of 4 loses 1 notch moving from a business risk profile of 4 to 5 or 5 to 6), while other declines in anchor rating for similar changes are two notches (e.g., a company with a financial risk profile of 4 loses 2 notches moving from a business risk profile of 1 to 2). S\&P's disclosures about its methodology do not make it possible to replicate these results or even understand the potential bases for them.

The revised S\&P methodology provides that there are additional rating factors that can modify the anchor rating. These include "diversification/portfolio effect, capital structure, financial policy, liquidity, and management and governance."231 S\&P's other ratings

230. Note that S\&P uses lower case letters for its anchor ratings, presumably to distinguish them from the final upper case letter ratings. For cells that have two possible ratings, S\&P states it will use the higher rating when the business risk profile is stronger, and the lower rating when it is weaker. See id.

231. Id. at 3. In the next section, I focus on the importance of the "diversification/portfolio effect," given the importance of correlation and diversification both in the financial crisis and today. 
adjustment factors also include variables and approaches that are also problematic and arbitrary in various ways, and then refer the reader to the relevant sections for details. For example, the final adjustments related to "capital structure" in the methodology include arbitrary assessments of a company's capital structure as "neutral," "negative," or "very negative." 232 Likewise, assessments of "financial policy" or "financial discipline" are "positive," "neutral," or "negative."233

\section{Discretion and Subjective Adjustments to Credit Ratings}

The analysis of the above variables is not the end of the methodological process. In addition to analyzing various credit risks, both Moody's and S\&P embed a significant amount of analyst discretion in their ratings. ${ }^{234}$ One possible rationale for doing so is that discretion preserves the capacity of rating agencies to avoid sudden upgrades and downgrades. In other words, discretion and subjectivity preserve stability.

Obviously, investors value stability. However, stability is less useful if it is achieved at the expense of accuracy and transparency. Moreover, any investor preference for stability is, at least in part, driven by reliance on ratings. Even the rating agencies admit that when investors rely on ratings as tools to constrain investment choices, it necessarily follows that they will prefer that those ratings remain stable, so that they are not continuously forced to trade their portfolios. For example, Moody's has noted that, "ratings are used by investors as governance tools to monitor and to constrain the investment choices available to portfolio managers they employ. When, for example, a security is downgraded into the speculative-grade rating range, some portfolio managers are required to sell their holdings." 235

Fudge factors such as "comparable ratings analysis" enable the rating agencies to achieve stability by avoiding transparency in their analysts' discretionary use of financial variables. ${ }^{236}$ Comparable ratings analysis 'reflects the need to 'fine-tune' ratings outcomes, even after the use of

232. See id. at 39.

233. See id. at $43-44,47-48$.

234. Studies of CDO ratings found that discretion and subjective adjustments were part of the approach to credit ratings before the financial crisis. See Griffin \& Tang, supra note 111, at 1293. The evidence discussed here shows that such subjectivity continues after the financial crisis.

235. See, e.g., MOODY'S INV'R SERV., MOODY'S SPECIAL COMMENT: ANALYZING the TRADEOFF BETWEEN RATINGS ACCURACY \& STABILITY 2 (2006).

236. S\&P's, CORPORATE METHODOLOGY, supra note 193, at 3 ("Comparable ratings analysis is the last analytical factor under the criteria to determine the final [rating] on a company."). 
each of the other modifiers." ${ }^{237}$ If the rating agencies' methodology led to accurate ratings, such fine-tuning typically would be unnecessary, or at least it would be rare. But S\&P has warned that, in fact, fudge factors are likely to be needed: "[a] positive or negative assessment is therefore likely to be common rather than exceptional.".238

Moreover, subjective adjustments can include issues or variables that no reasonable person would anticipate being part of a credit rating assessment. For example, S\&P's own descriptions acknowledge the subjective and arbitrary nature of subjective adjustments: "[w]e also consider additional factors not already covered, or existing factors not fully captured, in arriving at the [final rating]. Such factors will generally reflect less frequently observed credit characteristics, may be unique, or may reflect unpredictability or uncertain risk attributes, both positive and negative." 239

Recent research has found subjectivity matters in a deleterious way: the major credit rating agencies actually embrace and reward opacity and complexity. ${ }^{240}$ Specifically, the major credit rating agencies favor products that are more opaque and give higher ratings to more complex products. ${ }^{241}$ In other words, the credit rating agencies appear to be more willing to trust issuers or arrangers as it becomes more difficult to figure out the substance and risk of the products.

One explanation for the rating agencies rewarding opacity and complexity is that complex products are more likely to be rated based on trust, just as trust in information intermediaries rises when there is a

237. Id. at 12 .

238. Id. at 49. S\&P's "holistic" analysis is nakedly subjective:

A company receives a positive assessment if we believe, in aggregate, its relative ranking across the subfactors typically to be at the higher end of the range; A company receives a negative assessment if we believe, in aggregate, its relative ranking across the subfactors typically to be at the lower end of the range; A company receives a neutral assessment if we believe, in aggregate, its relative ranking across the subfactors typically to be in line with the middle of the range.

Id. at 50 .

239. See id. S\&P's changes in methodology appear to have be driven by result-related backtesting. For example, S\&P announced along with its methodological changes that:

We expect about $5 \%$ of corporate industrial companies and utilities ratings within the scope of the criteria to change. Of that number, we expect approximately $90 \%$ to receive a one-notch change, with the majority of the remainder receiving a two-notch change. We expect the ratio of upgrades to downgrades to be around 3:1.

Id. at 4 .

240. See Andra Ghent, Walter Torous \& Rossen Valkanov, Complexity in Structured Finance (Jan. 26, 2016) (unpublished manuscript), http://burridgecenter.colorado.edu/html/research/ Ghent_Andra_SecurityComplexity.pdf [https://perma.cc/8GRA-GNE7].

241. Id. 
need based on information asymmetry. Another theory is that complex products are an area where rating agency misbehavior becomes harder to observe. Complexity and opacity might be good for rating agencies, and perhaps even for some issuers, but they are not so good for investors. This new evidence suggests that rating agency methodologies continue to be opaque, just as they were before the financial crisis.

\section{B. Two Flaws}

I next turn to two specific examples of methodological flaws: the impact of diversification on credit ratings and the credit rating methodology applicable to investment holding companies. Both diversification and investment holding companies are areas that reveal ongoing methodological weaknesses in the major credit rating agencies' revised approaches.

\section{Diversification}

Mistaken assessments of diversification and correlation were at the core of the financial crisis. ${ }^{242}$ Both market participants and the credit rating agencies failed to understand the extent to which the default risks associated with various subprime mortgage-related assets were highly correlated, particularly given the effects of a sharp decline in housing prices. Correlation generally is one of the most difficult and complex topics in finance and financial practice. Unfortunately, S\&P treats diversification and correlation in a simplistic manner.

It is evident from S\&P's consideration of the impact of diversification on its revised methodology that it took the concepts of diversification correlation seriously. S\&P's degree of seriousness increased after it proposed revisions to its diversification-related methodology and received comments from market participants. For example, in its proposed revisions to its methodology-its initial draft of its methodology - S\&P used casual language, noting: "[u]nder the proposed criteria, diversification/portfolio effect applies to companies that we regard loosely as conglomerates. ${ }^{243} \mathrm{But}$ in the final methodology, the word "loosely" disappeared, even though the substance of S\&P proposed methodology survived intact. ${ }^{244} \mathrm{~S} \& \mathrm{P}$ apparently recognized the concerns

242. See Partnoy, Overdependence, supra note 17.

243. Standard \& Poor's Ratings Serv., Proposed Methodology, in Request For COMMENT: CORPORATE CRTERIA 38 (2013).

244. See S\&P's, CoRPORATE Methodology, supra note 193, at 37. 
about its approach to diversification and wanted to signal that its new methodology addressed those concerns by deleting the word "loosely."

In its revised methodological approach to diversification and correlation, S\&P enumerates three categories for a conglomerate's "diversification/portfolio effect": "1, significant diversification; 2, moderate diversification; or 3, neutral."245 An assessment of significant or moderate diversification potentially raises the issuer's anchor. ${ }^{246}$ To achieve an assessment of "significant diversification, an issuer should have "uncorrelated diversified businesses whose breadth is among the most comprehensive of all conglomerates'. ${ }^{247}$ To achieve an assessment of "moderate" diversification, an issuer typically would have a "range of uncorrelated diversified businesses that provide meaningful benefits of diversification with the expectation of lower earnings volatility through an economic cycle than an undiversified company's." 248

These distinctions are amorphous, and they have significant consequences. The "diversification/portfolio effect" is arguably one of the most important, if not the most important, modifications to the "anchor" rating in S\&P's new methodology. As the chart below shows, the diversification/portfolio effect can add as many as two notches to a company's rating. ${ }^{249}$

\begin{tabular}{|c|c|c|c|c|c|c|c|}
\hline \multicolumn{8}{|c|}{ Business Risk Profile } \\
\hline \multirow{4}{*}{$\begin{array}{c}\text { Diversification/ } \\
\text { Portfolio } \\
\text { Effect }\end{array}$} & & 1 & 2 & 3 & 4 & 5 & 6 \\
\hline & 1 & +2 & +2 & +2 & +1 & +1 & 0 \\
\hline & 2 & +1 & +1 & +1 & +1 & 0 & 0 \\
\hline & 3 & 0 & 0 & 0 & 0 & 0 & 0 \\
\hline
\end{tabular}

Table 5:

\section{Impact of Diversification/Portfolio Effect on the "Anchor Rating"}

The new S\&P criteria apply to "companies that we regard as conglomerates." 250 How does one determine whether to regard a company as a conglomerate? The answer appears at first to be a bright line: a conglomerate is a company with three significant and separate

245. See id. at 38.

246. Id.

247. See id. (noting that "[t]his assessment indicates that we expect the conglomerate's eamings volatility to be much lower through an economic cycle than an undiversified company's").

248. See id.

249. Id. at 9 .

250. See id. at 37 . 
business lines. ${ }^{251}$ However, the determination of whether a business "counts" as one of three separate business lines is subjective, with only rough guidelines about what "usually" would constitute a distinct business segment. ${ }^{252}$

Strangely, the conglomerate effect is only a plus or neutral factor (but not a negative one). ${ }^{253}$ The description of the methodology promises that, to the extent there are any negatives associated with a conglomerate, those will be captured elsewhere in S\&P's methodology. ${ }^{254}$ The extent of the overlap is not transparent: it is not clear how diversification, or a lack of diversification, would matter on a net basis to S\&P's adjustment.

Interestingly, in its new diversification-related methodology, S\&P stated that its revised approach was based on academic research. S\&P included a brief section in an appendix to its methodology, citing one academic article and one trade publication in support of S\&P's conclusion that diversified conglomerate firms had an advantage over single-sector focused firms. ${ }^{255}$

Generally, S\&P does not cite extensively to academic literature or engage with academic work to the same degree as Moody's. S\&P Global Ratings conferences are directed primarily at networking and describing S\&P ratings in different regions. ${ }^{256}$ In contrast, Moody's conferences, though also trade focused, tend to be more analytical and comprehensive. ${ }^{257}$ Moody's also takes a more academic and analytical approach generally, perhaps because of its 2002 acquisition of

251. See id. ("For the purpose of these criteria, a conglomerate would have at least three business lines, each contributing a material source of earnings and cash flow.").

252. See id. ("Usually the smallest of at least three distinct business segments/lines would contribute at least $10 \%$ of either EBITDA or FOCF and the largest would contribute no more than $50 \%$ of EBITDA or FOCF.").

253. See id. ("This assessment will have either a positive or neutral impact on the anchor.").

254. See id. ("We would capture any potential factor that weakens a company's diversification, including poor management, in our management and governance assessment.").

255. See id. at 70 (citing Venkat Kuppuswamy \& Belén Villalonga, Does Diversification Create Value in the Presence of External Financing Constraints? Evidence from the 2007-2009 Financial Crisis (Harv. Bus. Sch., Working Paper No. 10-101, 2010) and Philip Beckmann, et al., The Power of Diversified Companies During Crises, Bos. CONSUlting GRP.: BCG.PERSPECTIVES (Jan. 25, 2012), https://www.bcgperspectives.com/content/articles/value_creation_strategy_management_two _speed_economy_power_diversified_companies_during_crises/[https://perma.cc/C3F6-327L]).

256. See Webcasts \& Events, S\&P GLOBAL RATINGS, https://www.spratings.com/en_US/ webcasts-events [https://perma.cc/TA3Y-VUGN] (including the "Monte Carlo Reinsurance RoundTable" and the "Annual Nigeria Ratings \& Capital Markets Conference").

257. See Events, MOODY's CORP., https:/www.moodys.com/newsandevents/events [https://perma.cc/7UJV-WFW8] (including events on "Corporate Credit Rating Analysis" and "Moody's Project Finance Masterclass"). 
Kealhofer, McQuown, and Vasicek (KMV), a sophisticated provider of quantitative credit analytics. ${ }^{258}$ Moody's regularly interfaces with academic institutions and researchers, and its senior risk officer has been engaged regularly in research and has taught at top business schools. ${ }^{259}$ Moody's co-sponsors academic conferences and supports outside scholars who act as consultants and advisors. ${ }^{260}$

Accordingly, S\&P's reliance on academic research in this area is notable. Its reliance on these two articles in particular is significant for several reasons. First, S\&P's ratings methodology changed in a way that favored diversified conglomerate firms-and that disfavored undiversified firms - based on a cursory analysis of research about the financial crisis. Second, S\&P's ratings methodology change was based on market measures of risk. One of the key measures cited in the research was credit default swap spreads, which were lower during the crisis for conglomerate firms. ${ }^{261}$

More fundamentally, S\&P misinterpreted the research it cited. Even the Boston Consulting Group paper S\&P relied on-an unpublished work by consultants-concluded that conglomerates generally had an equity discount, meaning that the fact that a company was a conglomerate made it less-not more--valuable. ${ }^{262}$ To the extent the overall health and value of a company mattered to its ability to pay its debts, the fact that it is a conglomerate is an overall negative. In other words, based on the consulting paper S\&P cited, the diversification effect should have been the opposite of the one S\&P actually implemented.

258. See History of KMV, MOODY'S ANALYTICS, http://www.moodysanalytics.com/AboutUs/History/KMV-History [https:/perma.cc/VJ9P-EP3P].

259. See Bpeaker Bios: Richard MooDy's, https:/www.moodys.com/microsites/crc2010/bios.htm [https://perma.cc/4XQ5-RX7E] (describing Moody's Chief Risk Officer, Richard Cantor, who holds a Ph.D. in economics, was a researcher at the Federal Reserve Bank of New York, and has taught at UCLA, Ohio State, NYU, and Columbia).

260. See Moody's Academic Committee, MoODY's, https://www.moodys.com/microsites/ cre2010/mdyacad.htm [https:/perma.cc/3PW4-ZL2K] (describing Moody's "Academic Committee," which has been meeting semi-annually since 2001 and reviews and supports research). Both S\&P and Moody's also devote substantial resources to lobbying and political contributions See, e.g., Robert Schroeder, Moody's, S\&P Lobbying Spending on Rise, MARKETWATCH (Aug. 9, 2011, 2:37 PM), http:/www.marketwatch.com/story/moodys-sp-lobbying-spending-on-rise-201108-09 [https://perma.cc/L38J-XNGM] (citing estimates of 2010 lobbying expenditures of $\$ 1.65$ million for S\&P, $\$ 1.53$ million for Moody's, and $\$ 440,000$ for Fitch).

261. See S\&P's CORPORATE METHODOLOGY, supra note 193, at 70.

262. Philip Beckmann, et al., The Power of Diversified Companies During Crises, Bos. CONSULTING GRP.: BCG.PERSPECTIVES (Jan. 25, 2012), https://www.bcgperspectives.com/content/ articles/value_creation_strategy_management_two_speed_economy_power_diversified_companies _during_crises/ [https://perma.cc/C3F6-327L]). 
Moreover, to the extent the diversification benefit occurs, it appears to occur most predominantly during times of crisis. ${ }^{263}$ Accordingly, the accurate way to assess the effect of being a conglomerate would be that it would have an overall negative impact, but that this impact would be less negative during times of crisis. In other words, S\&P should overall give conglomerates a lower rating generally, but should include a mechanism that can quickly upgrade a conglomerate in times of crisis.

This is arguably the approach rating agencies should have taken to diversified pools of RMBS. Before the crisis, an accurate rating methodology would have given the various tranches significantly lower ratings. Then, when the crisis occurred, the ratings of the most diversified tranches should have been upgraded, not downgraded. Such an approach would achieve the counter-cyclicality favored by commentators on macro-prudential regulation. ${ }^{264}$

It is difficult to anticipate how significantly this change in ratings methodology might be. Since 2013, there has been a substantial increase in market-concentration driven mergers and acquisitions (M\&A) activity, in many cases unwinding the spin-offs and carve-outs that occurred during the 1980s and 1990s as businesses became more streamlined and efficient. ${ }^{265}$ Might credit ratings create incentives for 1960s-style conglomeration? Academic research has shown that even though there are theoretical arguments that diversified firms might increase profits and value by pooling different lines of business, in fact shares of diversified firms sell at a discount in the markets, in part because of the agency costs that arise for diversified firms. ${ }^{266}$

Moreover, the effects of diversification on corporate creditworthiness are far more complicated than the simplistic conclusion that diversified companies are less likely to default. For example, to the extent the markets regard diversified companies as more creditworthy due to their diversification, those companies will have lower cost of debt capital and perhaps greater levels of debt than they otherwise would have. A

263. See S\&P's CORPORATE MeThODOlOGy, supra note 193, at 70 (citing KupPUSWAMY \& VILLALONGA, supra note 255).

264. See Erik F. Gerding, Law, Bubbles, and Financial Regulation (2014).

265. See Gustavo Grullon, Yelena Larkin \& Roni Michaely, Are US Industries Becoming More Concentrated? (Oct. 2016) (unpublished manuscript) https://finance.eller.arizona.edu/sites/finance /files/grullon_11.4.16.pdf[https://perma.cc/77C2-YZ66].

266. See, e.g., Owen A. Lamont \& Christopher Polk, Does Diversification Destroy Value? Evidence from Industry Shocks, 63 J. FIN. ECON. 51 (2002), Raghuram Rajan, Henri Servaes \& Luigi Zingales, The Cost of Diversity: The Diversification Discount and Inefficient Investment, $55 \mathrm{~J}$. FIN. 35 (2000) (finding that diversification destroys value, consistent with the inefficient internal capital market hypothesis). 
company with a higher debt capacity due to diversification can assume more debt, and arguably has an optimal capital structure that includes more debt. Indeed, some research on the effects of diversification on capital structure conclude that, although there can be positive effects from diversification, there can be negative effects as well. ${ }^{267}$

In sum, with respect to the effects of diversification on corporate ratings, S\&P learned and implemented the opposite lessons it should have. Many market participants apparently failed to understand the extent of S\&P's rating change in this respect and have continued to rely on those ratings without making any adjustment for S\&P's new diversification-related methodology.

\section{Investment Holding Companies}

Whereas diversification is a factor in various ratings methodologies, it also is useful to look separately at the credit rating agencies' independent approaches to rating a particular group of issuers. Much of the above discussion related generally to corporate issuers. The Article now turns from the general corporate issuer approach to the particular methodologies that both Moody's and S\&P apply to the category of issuers known as "investment holding companies."268 This section discusses Moody's first, and then S\&P.

Investment holdings companies (IHCs) are a useful microcosm through which to view the major credit rating agencies' revised

267. See, e.g., Maurizio La Rocca, Tiziana La Rocca, Dionigi Gerace \& Ciorstan J. Smark, The Effect of Diversification on Capital Structure, 49 ACCT. \& FIN. 799 (2009) (citing various theories in the finance literature and demonstrating the potential of both positive and negative effects).

268. Moody's has published several documents describing its methodological approach to investment holding companies. See MOODY's CORP., GLOBAL INVESTMENT HOLDING COMPANIES: RATING METHODOLOGY (2007) [hereinafter MOODY's 2007 IHC METHODOLOGY] (describing the initial Moody's approach); MOODY's INV'RS SERV., INVESTMENT HOLdINGS COMPANIES: ONE SIZE DOES NOT FIT ALL (2015) [hereinafter MOODY'S ONE SIZE DOES NOT FIT ALL] (analyzing investment holding companies); MOODY's INV'RS SERV., INVESTMENT HOLDING COMPANIES AND CONGLOMERATES (2015) [hereinafter MOODY'S IHCS \& CONGLOMERATES] (describing Moody's revised methodological approach). S\&P also has published several documents, including as part of a request for comments process. See STANDARD \& POOR'S RATINGSDIRECT, RATING METHODOLOGY FOR EUROPEAN INVESTMENT HOLDING AND OPERATING HOLDING COMPANIES (2004) [hereinafter S\&P'S EUROPEAN HOLdING COMPANIES MEHODOLOGY] (describing the initial S\&P approach); STANDARD \& POOR's Ratings Serv., ReQuest For COMMENT: METHOdology: InVESTMENT HOLDING COMPANIES (2014) [hereinafter S\&P's 2014 RFC] (soliciting comments from market participants); STANDARd \& POOR'S RATINGS SERV., RFC PROCESS SUMMARY: METHOdOlogy: INVESTMENT HOLDING COMPANIES (2015) [hereinafter S\&P'S RFC PROCESS SUMMARY] (describing comments from market participants and responses); STANDARD \& POOR'S RATINGS SERV., METHodology: INVESTMENT Holding CoMpanies (2015) [hereinafter S\&P's 2015 IHC MEHODOLOGY] (describing S\&P's revised methodological approach). 
methodological approaches. IHCs are large and important issuers that present many of the fundamental challenges associated with credit ratings. Moreover, both Moody's and S\&P have recently reconsidered and published new methodological approaches to rating IHCs. Accordingly, they are a useful example to consider.

In October 2007, just as Moody's and other credit rating agencies were downgrading numerous subprime mortgage-related securities, Moody's published a new ratings methodology for IHCs. Moody's defined an IHC as "either a public or a private group holding entity ('Holdco') that acts as a financial investor." 269 Although the term "investment holding companies" generally has broad connotations, Moody's clarified that its use of the term "focuses more narrowly only on those companies for which the equity risk of subsidiaries is the main analytical driver, rather than their credit risk." 270

At the time, Moody's publicly rated only six investment holding companies. ${ }^{271}$ The total rated debt was just over $\$ 10$ billion, most of which consisted of medium-term note borrowing programs as opposed to actual outstanding borrowings. ${ }^{272}$ Accordingly, the total universe of rated debt in this area was relatively small.

Why would Moody's create a separate methodological category for investment holding companies? The main reason appears to be that the two alternative methodologies that most closely applied to these companies were problematic for various reasons. One such methodology was that for conglomerates (such as Hutchinson Whampoa or Imperial Holdings). Moody's rated numerous conglomerate holding companies, but in those cases the holding companies typically had a limited number (e.g., 3 to 5) of core assets in unrelated businesses that typically were majority owned and managed as a corporate group. The holding company conglomerates typically exercised strategic control of the subsidiaries, and potentially could shift credit support within the group. ${ }^{273}$

A separate methodology was for asset management companies (such as AllianceBernstein or Fidelity). Moody's rated numerous asset management companies, but in those cases the holding companies typically had a large number of investments in a wide range of assets

269. MOODY'S 2007 IHC METHODOLOGY, supra note 268 , at 3.

270. Id. at 1 .

271. Id. at 5 .

272. Id.

273. Id. at 4. 
that were held for investment purposes only. The asset manager provided investment services to investors and typically did not exercise strategic control or have the capacity to shift support. The mix of investments was variable and often included many short-term investments. There was no operational integration with any companies held within the investment portfolio.

Investment holding companies had some characteristics that fit each methodology. With respect to some investments, particularly those in which the IHC held a majority stake, the IHC might resemble a conglomerate group: it might be more actively involved and engaged in some operational aspects of a subsidiary business. But with respect to other investments, particularly for minority stakes, an investment holding company might follow more of an investment management strategy with less involvement. The degree of control and management also varied.

Moreover, there were other nuances among IHCs. Many IHCs had a history of being majority owned by a family (Moody's methodology excluded private equity firms). In addition, there might be financing at the parent investment holding company level, which was typically clearly separate and without recourse. For some IHCs, the parent typically did not provide guarantees to subsidiaries nor were there typically cross-default clauses associated with subsidiary debts. ${ }^{274}$ Accordingly, there was need for methodological clarification.

On October 8, 2015, Moody's published a research piece on IHCs entitled "One Size Does Not Fit All."275 The piece included qualitative and quantitative analysis of credit risk, and disclosed some details about each IHC it rated, including a rating, a rating outlook, and a description of various factors. It set forth five key ratings factors-asset quality, management discipline and transparency, market value based leverage, cash coverage, and liquidity - and gave each entity a rating score in each area ${ }^{276}$ Moody's mentioned the IHCs that were outliers in each area ${ }^{277}$ and noted that the boundary between IHCs and conglomerates was, in many respects, blurred. ${ }^{278}$

Moody's explicitly noted that the scoring of the key factors could be influenced by other factors. ${ }^{279}$ For example, an IHC's influence over

\footnotetext{
274. Id. at 3.

275. See MOOdY's ONE Size Does Not FIT ALL, supra note 268, at 1 .

276. Id.

277. See id. at 3-4.

278. See id. at 4.

279. Id. at 5 .
} 
dividends might reliably translate into strong interest coverage, but it also might not. ${ }^{280}$ Moody's included correlation-related issues, such as the relationship between IHC ratings and the ratings of their underlying investments. ${ }^{281}$ Moody's examined average debt maturities and accounted for the maturity differences among IHCs both quantitatively and qualitatively. ${ }^{282}$

Then, two months after issuing its analytics piece, Moody's published its revised ratings methodology for IHCs. ${ }^{283}$ This new methodology replaced its 2007 methodology. Moody's 2015 methodology uses the five above factors and weights them using a grid, not unlike S\&P's grid approach to corporate ratings.

Instead of translating factors into a score from one to six, Moody's simply uses its own ratings categories. For example, the "investment strategy" sub-factor carries a $10 \%$ weight and Moody's describes what kind of judgment it would need to make about an IHC's investment strategy to give it a Aa rating or a Baa rating. ${ }^{284}$ Likewise, asset quality carries a $40 \%$ weight and Moody's describes similar kinds of judgments. ${ }^{285}$ Some of the analysis is quantitative, such as that for asset concentration, where "minimal concentration" means that the market value of the three largest investments is less than $10 \%$ of the total portfolio market value. ${ }^{286}$ Likewise, "business diversity" is calculated based on the number of sectors an IHC is invested in: more than thirteen sectors is Aaa; four to five sectors is $\mathrm{Ba}^{287}$ Other factors, such as "investment portfolio transparency"288 are qualitative and include substantial latitude for analyst judgment and discretion.

S\&P's approach historically has included many of the same weaknesses inherent in Moody's approach. S\&P's corporate methodology does not cover IHCs. Indeed, before 2014, S\&P approached IHCs as a separate part of its methodology for two categories of firms-European investment holding companies and operating holding companies-both of which were covered by related

280. See id.

281. See id. at 11-12.

282. See id. at 14-15.

283. See MOODY'S IHCS \& CONGLOMERATES, supra note 268, at 1.

284. Id. at $10-11$

285. Id. at $12-14$.

286. Id. at 12,14

287. Id. at 14 .

288. Id. 
methodologies. ${ }^{289}$ In its initial approach, published in 2004, S\&P explicitly noted that its methodologies varied by company and depended on unique factors that combined portions of S\&P's approach to industrial conglomerates, investment holding companies, and operating holding companies. ${ }^{290}$

On November 26, 2014, S\&P published a request for comment on its proposed revisions to the approach it used to rate IHCs. ${ }^{291}$ On December 1,2015 , after receiving feedback from market participants, S\&P then published its final criteria for IHCs. ${ }^{292}$

S\&P's prior methodology was qualitative and free form, leaving much of the analytical judgment and credit assessment to the ratings analyst. Its revised methodology is more structured, with factors such CICRA, discussed above. ${ }^{293}$ It essentially imports S\&P's new corporate methodology, thereby importing all of the flaws discussed above into its methodological approach to rating IHCs.

S\&P's IHC methodology is not responsive to the basic idea of a credit rating: to be an assessment of the individual issuer's underlying credit quality. Both qualitative and quantitative factors matter to ratings. Obviously, qualitative factors should be evaluated in a qualitative way; quantitative factors should be evaluated in a quantitative way. A fundamental difficulty arises when qualitative factors are scored in a quantitative way, and then quantitative adjustments are made in ways that become unmoored from any reasonable qualitative analysis. For example, some issuers have debt due immediately; others have longerterm debt. The amount, maturity, and structure of debt are quantitative factors. Yet equally relevant are qualitative factors about that debt: how has it been managed historically, are there any unique features, how is cash used when debt is issued?

The flaws in S\&P's inflexible approach are illustrated by its own requests for comment. On November 26, 2014, in its proposed methodology, S\&P rated the IHC universe as "moderately high risk" category-category $4 .{ }^{294} \mathrm{~S} \& \mathrm{P}$ then copied the relevant methodology

289. See S\&P's European Holding Companies Methodology, supra note 268, at 1. The coupling of these two categories appears to have been related to S\&P's organizational structure, and the European analysis that covered individual firms in each category. See id. at 1 (listing four primary credit analysts in the areas).

290. See id. at 1-8.

291. See S\&P'S, RFC PROCESS SUMMARY, supra note 268, at 3.

292. See id.

293. Id. at 13-14.

294. See S\&P's 2014 RFC, supra note 268 , at 7. 
from its corporate ratings for category 4. Then, on December 1, 2015, in its final approach, S\&P rated the IHC universe as "intermediate risk"category $3 .{ }^{295} \mathrm{~S} \& \mathrm{P}$ then copied the quite different relevant methodology from its corporate ratings for category 3. S\&P did not cite any evidence that IHC credit quality changed substantially from 2014 to 2015 , and my research uncovered no such evidence. Yet the effect of its change was that it inflexibly imported a different approach.

Another problem is apparent from S\&P's proposed approach to anchor ratings for IHCs, which would have been capped at aa regardless of financial risk score. IHCs appeared in category 4, indicating moderately high risk. But that proposed approach was obviously flawed: it treated IHCs as categorically riskier than both regulated utilities and pharmaceutical companies, for example. In fact, such a comparison is inapt: many IHCs are far less risky and the comparison is obviously apples to oranges.

S\&P revised its proposed IHC methodology in response to comments, and its final methodology reflects the relatively high credit quality and liquidity of many IHC issuers. But S\&P's abrupt reversal is telling. S\&P's methodological approach required a methodology that generalized about IHC issuers as being either "moderately high risk" or "intermediate risk." This generalization then significantly impacted the treatment of different issuers. A high-quality IHC issuer would be rated more accurately in category 3. But a low-quality IHC issuer would be rated more accurately in category 4 . Thus, both S\&P's old and new approaches lack the flexibility to arrive at accurate categories for individual IHCs.

S\&P's insistence on shoehorning IHCs into aspects of its corporate ratings framework makes little sense. For example, the effect of S\&P's determination that IHCs generally fit category 3 is simply to truncate the CICRA versus investment position table, so that only CICRA categories 3,4 , and 6 are represented. As S\&P states in a footnote, "*CICRA assessments of (1), (2), and (5) do not apply to IHCs due to our assessed industry risk assessment of 'intermediate' (3)." 296 Those categories might accurately describe some IHCs, but that doesn't matter in S\&P's methodology, which leads them simply to disappear. More generally, the categorical industry risk scores do not capture the underlying credit quality of an individual IHC. As noted above, the IHC industry is not homogenous. IHCs invest in different categories of assets, in different 
industries, with different credit qualities and risks. Some IHCs use debt to finance asset purchases; others do not. IHC debt varies substantially in maturity and structure. S\&P's IHC framework does not adequately account for this granularity. Nor does S\&P's methodology reward IHCs with good liquidity, management, or governance; instead, the focus is on downside adjustments. ${ }^{297}$

Some of S\&P's proposed methodology was so arbitrary and inaccurate that it rose to the level of embarrassment. For example, S\&P proposed a table that "classifies listed equity investments into four equity market groups by country, based on the volatility we have observed in that country's main stock market index over the past 30 years. ${ }^{298}$ S\&P then proposed using a thirty-year volatility measure of a country's main stock index as an indicator of liquidity. The result of this approach was "Equity Market Groups" (EMGs), which separated countries into four categories.

The EMGs categorizations were stunningly wrongheaded, and even contradicted S\&P's own ratings. For example, EMG 2 contained AsiaPacific, Belgium, Canada, Denmark, European Union, France, Germany, Hungary, Israel, Italy, Japan, Luxembourg, Mexico, Netherlands, New Zealand, Norway, Portugal, Slovak Republic, Slovenia, South Africa, Southeast Asia, Spain, Sweden. EMG 3 contained Austria, Bahrain, Baltic, Caribbean, Cyprus, Czech Republic, Dominican Republic, Eastern Europe, Estonia, Finland, Greece, Gulf Cooperation Council, Hong Kong, Indonesia, Ireland, Jamaica, Korea, Kuwait, Latvia, Lithuania, Malaysia, Malta, Oman, Philippines, Qatar, Saudi Arabia, Singapore, Taiwan, Trinidad and Tobago, Turkey, United Arab Emirates. ${ }^{299}$

These two EMG categories made little sense. For example, S\&P's proposed methodology would have treated IHCs with exposure to Mexico more favorably than those exposed to the United Arab Emirates, or IHCs with exposure to Spain more favorably than those exposed to Singapore. It also was striking that creditworthy sovereigns in major financial centers, such as Hong Kong and Singapore, were grouped with countries like Cyprus, Greece, and Latvia. Strangely, regions such as "Asia-Pacific" and "Southeast Asia" were in EMG 2, along with Spain, Portugal, Slovenia, and the Slovak Republic, while several individual countries in the Asia-Pacific and Southeast Asia regions were in EMG 3.

297. Id. at $14-19$.

298. S\&P's 2014 RFC, supra note 268 , at 10.

299. Id. at 10-11. 
This aspect of S\&P's methodological treatment was important, too: an IHC with a majority of its assets traded in countries rated EMG 3 or 4 would have been subject to a cap with respect to this component. In other words, an IHC with the majority of its assets traded in Hong Kong would have a cap, whereas an IHC with the majority of its assets traded in the Slovak Republic would not. S\&P's proposed methodology was obviously flawed.

S\&P ultimately scrapped the concept of EMGs in its final IHC methodology, although it continued to rely on its Country Risk Assessment Methodology and Assumptions, which remained intact. ${ }^{300}$ In other words, S\&P deleted some of the offending specific details in its proposed framework but retained the underlying country risk framework. Nevertheless, the fact that S\&P proposed such a silly methodological approach is telling. It also is significant that $\mathrm{S} \& \mathrm{P}$ on its own, without input from market participants, would have implemented such an approach.

One equally dubious concept that $\mathrm{S} \& \mathrm{P}$ proposed-and then retained in its final methodology-is a liquidity assessment based on the proportion of public versus private investments held by IHCs. S\&P applies a simplistic formula to the percentage of publicly listed companies held by an IHC and then mechanically arrives at a liquidity assessment based on that percentage. According to S\&P, "we view a significant investment in unlisted assets as a fundamental underlying weakness for an IHC." 301 Accordingly, an IHC that holds more than $80 \%$ listed companies receives a higher assessment than an IHC with $80 \%$ or below, $70 \%$ or below, and so on. The formula applies without regard to the actual liquidity of the underlying investments. In other words, some publicly listed securities might be illiquid, yet nevertheless receive a credit based on S\&P's liquidity assessment. Conversely, some unlisted securities might be relatively liquid (even though they are not traded on an exchange), but result in a lower assessment. Moreover, the formula ignores the fact that a company might hold unlisted securities of an entity that held stakes in publicly listed companies.

In modern markets, there are good reasons for IHCs, or any investor, to hold substantial stakes in companies that are not publicly listed. The number of publicly listed companies is declining, and public companies are subject to onerous and costly reporting requirements. Unlisted

300. See S\&P's 2015 IHC METHODOLOGY, supra note 268, at 8 (describing "Country Risk" and referencing S\&P's “Country Risk Assessment Methodology and Assumptions”).

301. Id. at 10 . 
companies have the potential to benefit from a range of business opportunities, including the positive price performance of an initial public offering. Increasingly, privately listed companies, such as numerous "unicorns" (with more than a billion dollars of market capitalization), are exploring secondary trading markets that provide liquidity to investors. S\&P's liquidity assessment ignores these nuances.

More generally, S\&P's IHC framework also suffers from the fundamental problem of quantifying qualitative factors. For example, consider S\&P's treatment of what it calls "Strategic Investment Capability." 302 S\&P scores five SIC factors-investment discipline, risk analysis, return analysis, portfolio rotation, and value creation-on a three-point scale. ${ }^{303}$ Each factor is rated as above average, average, or below average. ${ }^{304}$ The criteria for each determination are often vague or indeterminate. For example, portfolio rotation is evaluated as "above average" if the IHC makes disposals "periodically," is committed to "an effective strategy of portfolio rotation," and "quickly" reinvests proceeds. ${ }^{305}$ Likewise, S\&P categorizes IHCs generally as "intermediate risk" (meaning Industry Risk category 3 ) based exclusively on the IHC business model, without regard to the quantum of dividends or cash flows received relative to an IHC's financial obligations. ${ }^{306}$

Thus, S\&P's methodological framework for IHCs exhibits many of the same flaws that have plagued its earlier approaches. In particular, S\&P's approach to determining both business risk and financial risk profiles is seriously flawed, including its ill-conceived categorical approach to investment positions, asset risk, and leverage. S\&P also employs arbitrary methodologies to combine business risk and financial risk profiles, as well as the other various proposed modifications and considerations that are important parts of S\&P's framework.

As noted above, a sophisticated analysis of IHC credit would differ markedly from the Moody's and S\&P approaches. The analysis would include more subtle and sophisticated methods, including more specific analyses of financial ratios, income and cash flow variables, foreign exposure, document terms, option-adjusted valuation, simulations and stress tests, and analyses of recovery rates, market prices, and other variables. ${ }^{307}$ Moody's and S\&P's methodologies are not sophisticated.

302. See id. at $12-13$.

303. Id.

304. Id.

305. See id. at 13.

306. See id. at $7-8$.

307. See Howe, supra note 10; Kamakura, supra note 10; Jankowitsch, Nagler \& 
In sum, IHCs are a useful microcosm of the ongoing problems associated with credit rating agencies. My main empirical point here is that the problems are, at their core, methodological. Both Moody's and S\&P have opaque and often arbitrary ratings methodologies that benefit from opacity. There are few, if any, reputational, regulatory, or liability consequences related to its use of these flawed methodologies. Nevertheless, the ratings that result from the methodologies seem to have value in the marketplace. This is the continuing paradox of credit ratings: value without useful information.

Overall, the above empirical investigation demonstrates that the major credit rating agencies have not substantially improved their methodological approaches since Dodd-Frank. Given the lack of oversight and accountability of credit rating agencies, this lack of improvement should not be surprising. Unfortunately, flawed methodologies remain part of what is (still) wrong with credit rating agencies.

How might credit rating agencies be persuaded to improve their methodologies? In addition to the oversight and accountability recommendations above, the OCR might explore the agencies' diversification and IHC methodologies during its upcoming annual reviews. SEC rules implemented pursuant to Dodd-Frank require that NRSROs "have policies and procedures" relating to their procedures and methodologies for determining credit ratings. ${ }^{308}$ The above analysis demonstrates significant errors with respect to those methodologies. Arguably, Moody's and S\&P should be required to publicize those errors, perhaps by posting a copy of this Article to an easily accessible portion of its corporate website..$^{309}$

This section has illustrated the serious and ongoing methodological flaws at the major credit rating agencies. One normative conclusion that arises from these flaws is simple: the agencies should improve their methodologies. But another, perhaps even more important conclusion and the central point of this Article is that to the extent these methologies do not improve, and accordingly credit ratings continue to

Subrahmanyam, supra note 46, at 156.

308. See Press Release, SEC, SEC Adopts Credit Rating Agency Reform Rules (Aug. 27, 2014), https://www.sec.gov/news/pressrelease/2014-178.html [https://perma.cc/4C6U-S7CV].

309. The rating agencies are required to publish policies and procedures related to significant errors on an "easily accessible" portion of their website. See August 2014 Amendments to Existing Rules and New Rules That Apply to Nationally Recognized Statistical Rating Organizations, Providers of Due Diligence Services for Asset-Backed Securities, and Issuers and Underwriters of Asset-Backed Securities in Accord, SEC (June 13, 2015), https://www.sec.gov/info/smallbus/secg/ nrsro-amendements-small-entity-compliance-guide.htm\#fn 1 [https://perma.cc/RRW5-6G9V]. 
have little informational value, investors should not rely on credit ratings.

\section{CONCLUSION}

Some scholars have expressed skepticism about whether market participants can process complex financial information, particularly about structured finance and derivatives. ${ }^{310}$ Others have noted that market discipline often fails in financial regulation. ${ }^{311}$ These arguments suggest that information intermediaries can serve an important function in financial markets by filtering, processing, sorting, and condensing information.

Unfortunately, decades of regulatory reliance have perverted this potentially valuable function with respect to the role of credit rating agencies. Dodd-Frank partially addressed this "regulatory license" problem, but many market participants continue to rely mechanistically on credit ratings. Regulatory licenses have proven to be quite sticky.

Moreover, letter ratings are a crude mechanism for information intermediation. Letter ratings obscure the analysis of the key variables that matter in the analysis of credit: probability of default, expected recovery in the event of default, and the correlation of defaults. The methodologies critiqued in this Article are disconnected from that analysis.

As of 2017, enough time had passed since the financial crisis and the resulting legal reforms to assess how much the credit rating industry has changed. The answer: not much. The major credit rating agencies continue to generate little informational value, and yet be rewarded handsomely for their ratings. They continue to operate as an oligopoly with special regulatory treatment. Congress should not permit the rating agencies-and the SEC-to flout Dodd-Frank. But even if Congress remains silent, investors should respond by reducing their reliance on credit ratings.

310. See Robert P. Bartlett, Inefficiencies in the Information Thicket: A Case Study of Derivative Disclosures During the Financial Crisis, 36 J. CORP. L. 1 (2010).

311. See David Min, Understanding the Failures of Market Discipline, 92 WASH. U. L. REV. 1421 (2015). 